\title{
A study of the Floral Biology of Victoria amazonica (Poepp.) Sowerby (Nymphaeaceae)
}

\author{
Ghillean T. Prance (1) \\ Jorge R. Arias [2]
}

\begin{abstract}
A field study of the floral biology of Victoria amazonica (Poepp.) Sowerby (Nymphaeaceae) was made for comparison with the many studies made in cultivated plants, of Victoria in the past. In the study areas in the vicinity of Manaus, four species of Dynastid beetles were found in flowers of $\mathrm{V}$. amazonica, three of the genus Cyclocephaia and one of Ligyrus. The commonest species of beetle proved to be a new species of Cyclocephala and was found in over 90 percent of the flowers studied. The flowers of $\mathbf{V}$. amazonica attract beetles by their odour and their white colour on the first day that they open. The beetles are trapped in the flower for twenty-four hours and feed on the starchy carpellary appendages. Observations were made of flower temperature, which is elevated up to $11^{\circ} \mathrm{C}$ above ambient temperature, when the flower emits the odour to attract the beetles. Observations on beetle frequency, the number of floral parts, seed dispersal and the evolutionary development of cantharophily are also presented.
\end{abstract}

\section{INTRODUCTION}

We, a botanist and an entomologist working together in Amazonia, decided to investigate the floral biology of Victoria amazonica. Since the subject proved very interesting the study became more detailed than we had originally intended it to be. Although there is much literature about the floral biology of Victoria, most of the significant work has been carried out in greenhouses in Europe, and not in the plant's native habitat. Accordingly, we have tried to study the plant in central Amazonia over a one-year period, in order to confirm observations made in greenhouses, to integrate the various other studies made in the field of some aspects of the subject, to find out more about the inter-relation between
Victoria and the beetles which visit the flowers in large numbers, and to collect data on $V$. amazonica to compare with the data of Valla \& Cirino (1972) on V. cruziana.

\section{HISTORY OF WORK ON THE FLORAL BIOLOGY OF VICTORIA}

The nomenclatural and taxonomic history of the genus has already been summarized in Prance $(1974)$, where it has been shown that the correct name for the Amazonian species of Victoria is $V$. amazonica, and not the more frequently used name, $V$. regia. The taxonomic history is not treated further here.

Victoria amazonica has been a subject of interest in Amazonia for many years, and there are several extant versions of the Indian legend attached to the plant. One of these versions is given below. It shows that the Tupi Indians regarded the flowers of Victoria as objects of great beauty.

\section{The Tupi Legend of Victoria}

The elders of the tribe say that Naue, the beautiful daughter of the chieftain, fell in love with the moon when she saw its reflection in the water one night. From then on Naue went to look at the reflection, which, the shaman said, was the prince of the region of Iuaca. After several days the moon disappeared from the lake, and Naue became very sad and fell sick for a month. One night in her love-sick delirium Naue saw the moon reflected again in the lake, and to embrace the body of her lover she threw herself in the water and disappeared. Tupã the god touched by the fate of Nauê transformed her into the most beautiful flower of the lakes, Victoria amazonica.

Many years after the Indian legend came into existence, Victoria amazonica was discovered by scientists of the western world, and

\footnotetext{
(1) - Instituto Nacional de Pesquisas da Amazônia e B. A. Krukoff Curator of Amazonian Botany, The New York Botanical Garden.

(2) - Instituto Nacional de Pesquisas da Amazônia, Manaus.
} 
from the first they made observations and comments on aspects of the floral biology. Schomburgk, (1837), was the first botanist to note the presence of beetles in the flowers of $V$. amazonica. Schomburgk mentioned the genus Trichius as the possible identification of the beetles, and this observation was repeated by Lindley (1838) in his description of the synonym Victoria regia based on Schomburgk's material.

Bridges, (in Hooker 1847), described the evening opening of the flowers and noted the change of colour in the petals. He also described the fruity smell of the flowers of Victoria which he had observed in Bolivia.

Fitch and Hooker, (1851), made observations on the first opening of the first greenhouse material to flower in England.

Planchon, (1850-1851), was the first person to comment on the temperature difference between the air and the interior of the flower. $\mathrm{He}$ recorded a $6^{\circ} \mathrm{C}$. difference in the material grown in Ghent, Belgium. Otto (1952), also investigated the flower temperature in material grown at Hamburg, and recorded a $5^{\circ}$ temperature difference.

Caspary $(1855 a, b)$ also made detailed studies of the temperature changes (see Fig. 1) and commented that cross-pollination was necessary for seed-set; an observation which was later disproved by various workers, including the present ones.

The most detailed European work on the floral biology of $V$. amazonica is that of Knoch (1899), who studied the anatomy, the flower opening, and the temperature changes of cultivated material. Knoch studied the temperature changes of individual parts of the flower in considerable detail, and showed that most of the heat is generated from the carpellary appendages, but that the paracarpels also produce heat. (The terms used here for these parts follow those of Caspary, (1878), and of Knoch, as there has been much confusion in the nomenclature of the floral parts). Knoch compared his results with those of Caspary. The maximum temperature difference between ambient and flower which he recorded was $10.2^{\circ} \mathrm{C}$ at $19: 15$ hours $\left({ }^{3}\right)$. Knoch observed the flowers opening in the early evening, and emmitting a strong odour at that time, the flowers closing the following morning, changing colour during the day and reopening on the second day between 17:00 and 18:00 hours, when the pollen was released. $\mathrm{He}$ could not observe the pollinators in Germany, but assumed that they were trapped in the flower during the second day, and released when the flowers opened to release the pollen. He also noted that self-pollination was possible, and that the fertilized flowers soon became submerged. Knoch also studied the physiology and chemistry of the carpellary appendages, including the chemical changes which took place during flowering and the $\mathrm{CO}_{2}$ released by the respiration.

Malme, (1907), in a detailed taxonomic discussion of $V$. cruziana treats the floral biology little, but he refers to previous work, such as that of Knoch and Caspary, and cites Cyclocephala as a visitor to the flowers.

Archangeli, (1908), made a similar study of $V$. amazonica grown at Pisa, Italy. He concentrated on the fertilization aspects, and obtained reasonable seed-set from self-fertilization. He found that the stigma remained receptive on the second night. Archangeli refered to the literature citing the scarab beetle Cyclocephala castanea Oliv. as the pollinator. and he commented that it was probable that more than one species of beetle was involved in the pollination; a fact that we have now established.

Decker, (1939), said that flowers studied in Amazonian Brazil showed a temperature difference of $11^{\circ}-14^{\circ} \mathrm{C}$, between the environment and the flower interior. He also said that self-fertilization did not occur in $V$. amazonica.

Many other authors of the present century have commented on these observations, or have repeated in part the work of some of the previous workers, for example: Arbor (1920), Knoll (1956), Werth (1956), Meeuse (1961), Percival (1965), Sculthorpe (1967), Kugler (1970), Gottsberger (1974), Weidlich (pers. comm.).

(3) - Some of his results are reproduced here for comparison with our results. (Fig. 2). 


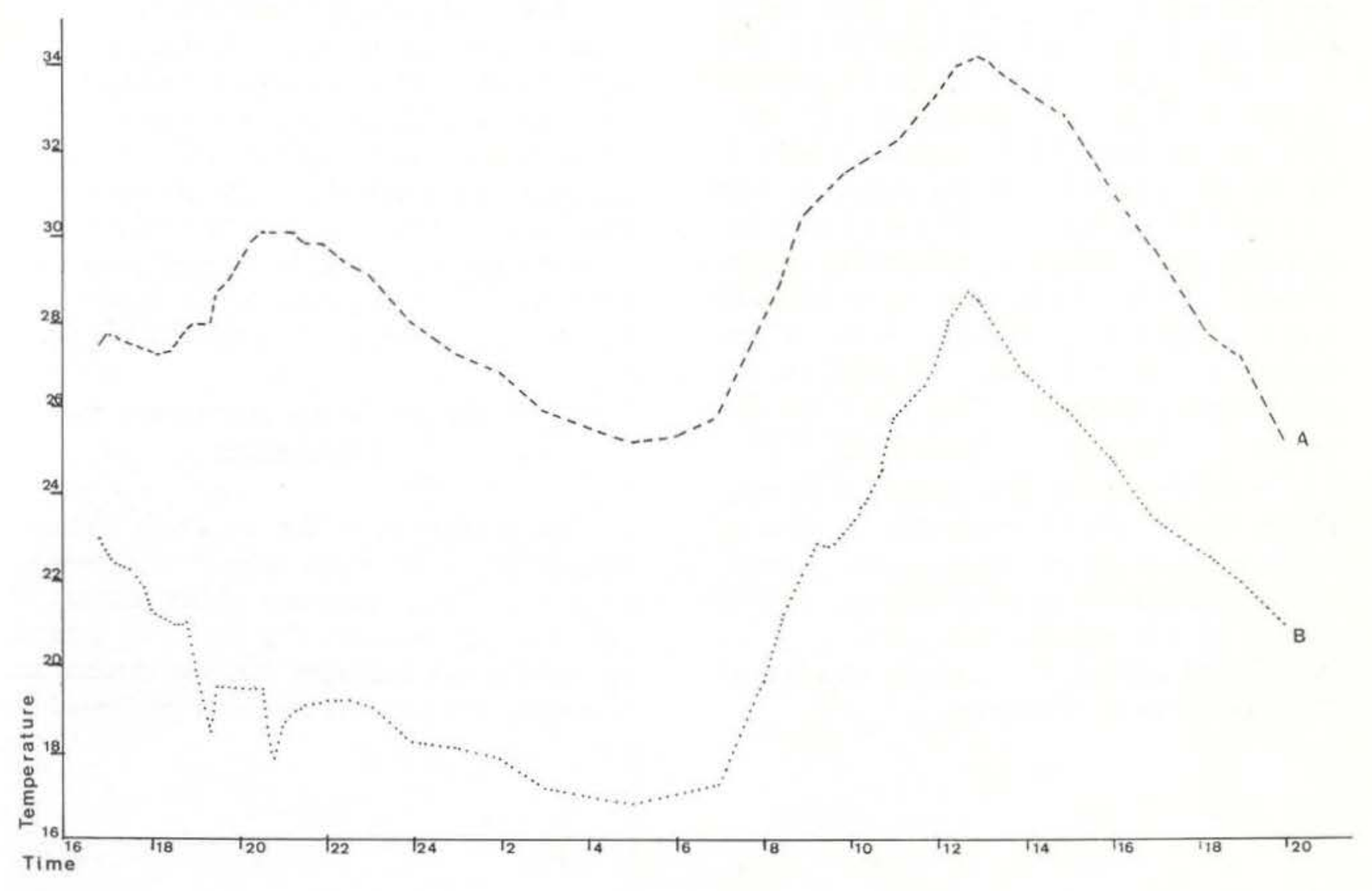

Fig. 1. Graph of Caspary's results (1855) of the temperature of V. amazonica flowers. A flower temperature B: air temperature.

Gessner, $(1960,1962)$, studied the flower opening and showed clearly that it was related to light intensity. The flowers opened as darkness increased. He showed, by masking flowers, that they could close in darkness at any time after 16:00 hours. He also cited the presence of the scarab beetle Cyclocephala castanea Oliv.

Valla and Cirino (1972) made a detailed two-month study of the floral biology of Victoria cruziana, in its native habitat, in the Province of Corrientes, Argentina. Their interesting work enabled us to compare some aspects of our work on $V$. amazonica with some aspects of the biology of $V$. cruziana. Valla and Cirino studied flower opening which began between 16:00 and 17:00 hours in March and April," and found it to be correlated with light intensity. They gave details and figures of the opening and closing processes of the flower, which correspond closely to our own observa- tions in V. amazonica, and they noted the colour and smell changes in the flowers. They studied the emission of odour using the neutral red technique described by Vogel (1962), and showed that the odour came from the petals as well as from the interior of the flower. They made temperature readings and recorded a maximum of $7.5^{\circ} \mathrm{C}$ difference between the air and the flower interior. Unfortunately, their temperature readings were made in cut flowers taken to the laboratory, so that we do not have an exact comparison with our results which were obtained in the field. They found only one scarab beetle in all the flowers which they studied (Chalepides sp. - Cyclocephalinae). Thus they did not obtain much pollination data which could be compared with those of $V$. amazonica. They attributed the lack of pollinators to the fact that the study area was at the edge of the distribution range of the species, and mentio- 
ned that species with good pollination mechanisms might also have the capacity for selffertilization to enable the continued dispersal outside the range of the normal pollinator. They commented that the floating seeds of V. cruziana enabled it to be dispersed long distances by water. The ability of normally cross-pollinated species to self-pollinate under adverse conditions is well-known and has been much commented on in many studies of the migration of species, especially in island and trans-oceanic migration. This has been discussed in some detail by Baker $(1955,1961)$.

In addition to the floral biology work cited above, several other interesting aspects of Victoria have been studied, for example Gessner (1950) studied the stomata of both species of Victoria, and Heinsbroek and Van Heel (1969) studied the vascular anatomy of the stamens of $V$. amazonica.
The chromosome numbers of Victoria were studied by Langlet \& Söderberg (1929) who cite $2 n=20$ in V. amazonica and $2 n=24$ in $V$. cruziana. They also refer to a hydrid between the two species with $2 \mathrm{n}=22$. These numbers fall within the range of other Nymphaeaceae but $V$. amazonica is slightly lower than any other reported by Langlet and Söderberg. The genus Cabomba has a diploid number of 24, Nymphaea 28-224 and Euryale 58.

\section{A SUMMARY OF THE MECHANISM OF POLLINATION}

As a background for our own detailed results, which are given later, it is necessary to give a general summary of the process of pollination in Victoria. The historical summary given above indicates that the mechanism by which Victoria amazonica is pollinated by

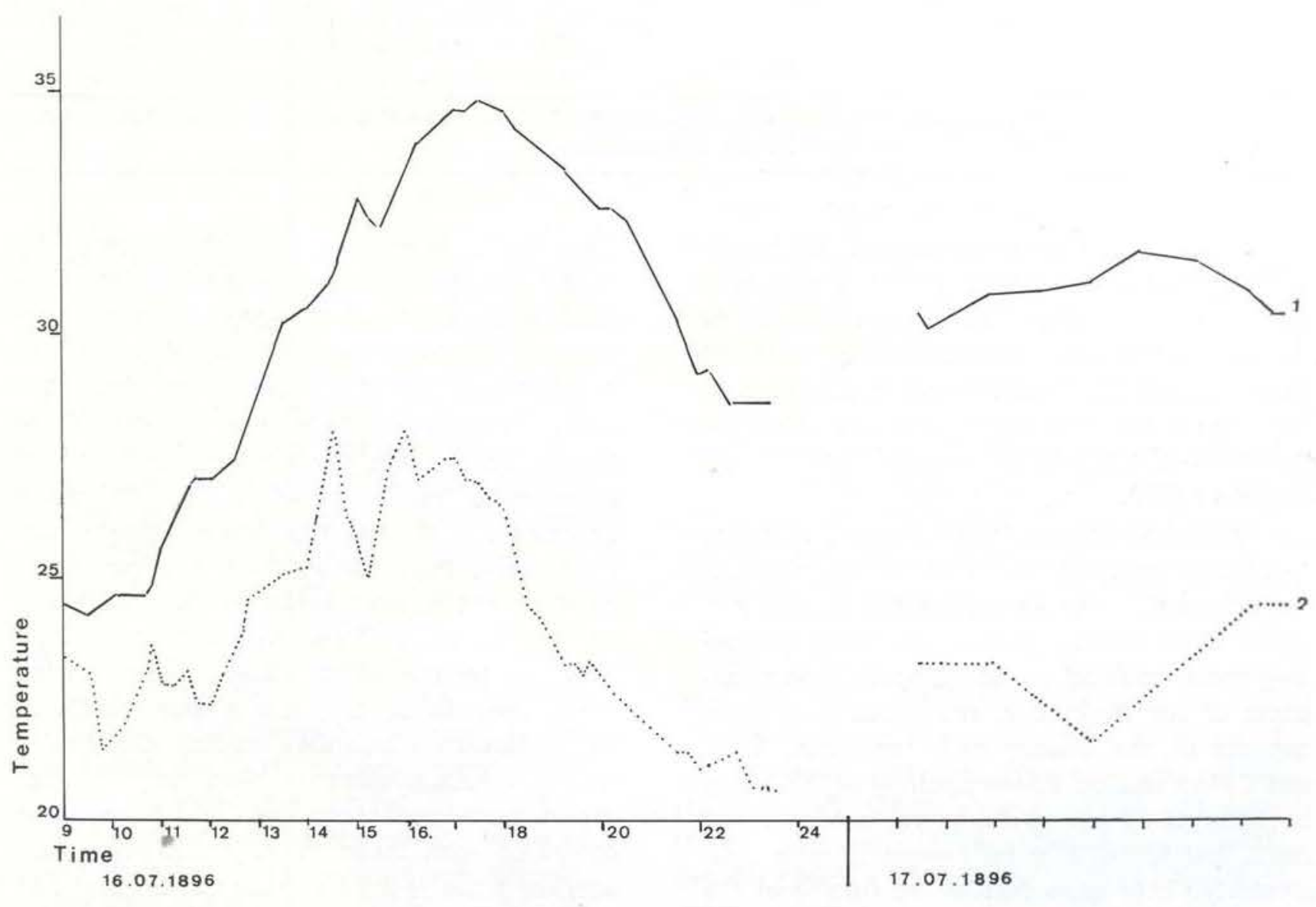

Fig. 2. Graph of one of Knoch's (1899) flower temperature readings of V. amazonica. 1: flower; 2 air. 


$$
\begin{aligned}
& M m \\
& W^{2}
\end{aligned}
$$




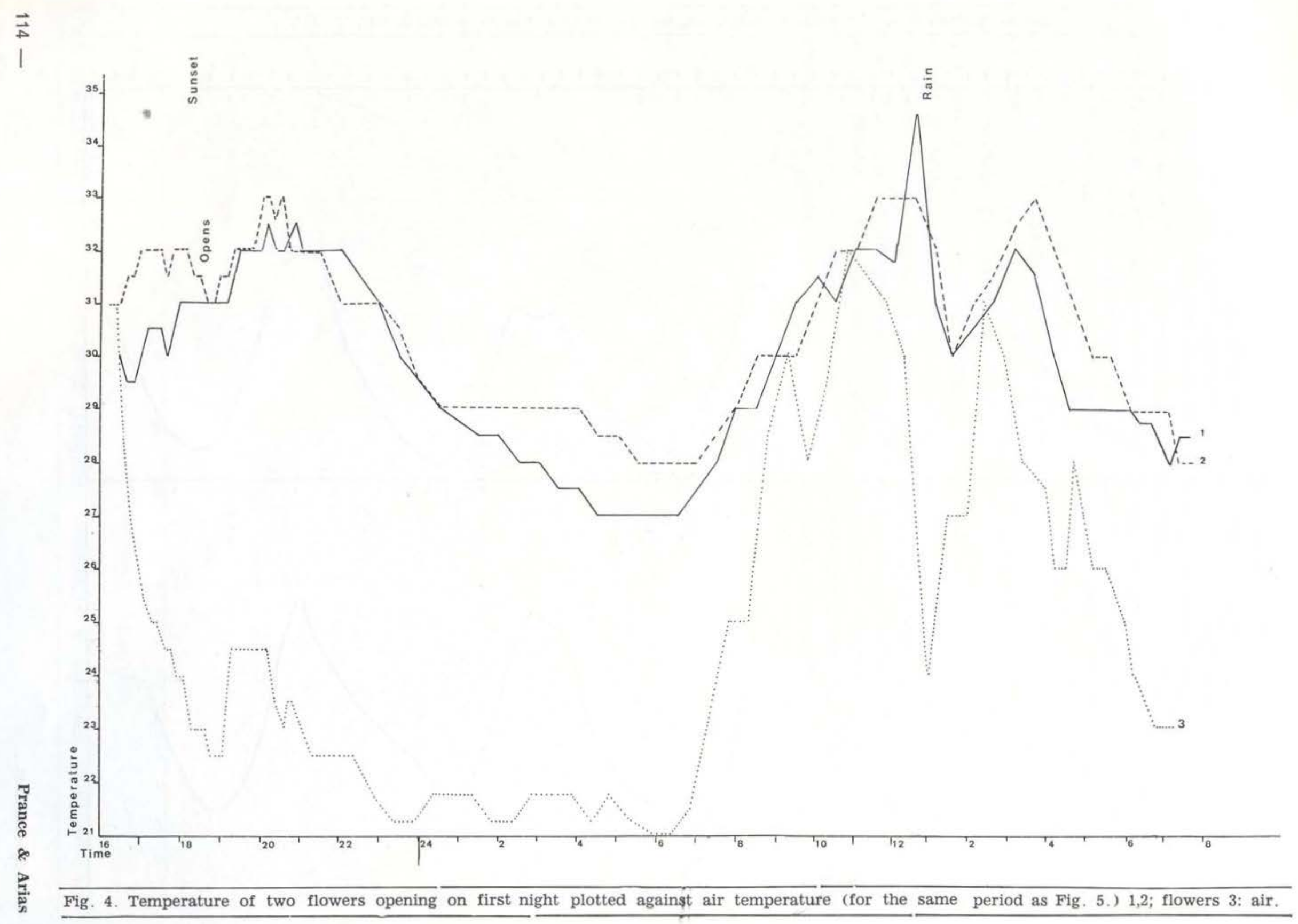


species of Dynastid beetles is interesting. The flowers have 100-300 stamens surrounded by sterile staminodes without and paracarpels within. These floral parts have a mechanism to trap the beetles inside the flowers for about 24 hours. (Fig. 9).

In its native habitat in Amazonia the flowers of $V$. amazonica always open between 17:30 hours and 18:30 hours on their first day of opening. The exact time depends directly on light intensity. Gessner $(1960,1962)$, showed clearly that flower opening is directly correlated with light intensity. The flowers open as dusk falls. Consequently all buds which are ready to open in any patch of $V$. amazonica open at approximately the same time. It is spectacular to watch this in an area where there are many individuals of the plant. When the flowers first open the petals are white, and during this first night the gynoecium and staminodes are elevated as much as $11^{\circ} \mathrm{C}$ above air temperature. At the same time the flowers emit a strong fruit odour (reminiscent of a mixture of butter-scotch and pineapple). These facts have been known for a long time, e.g. Planchon $(1850,1851)$ Schumann (1894), Knoch (1899), but most observations have been made in greenhouse plants rather than in plants in their natural habitat in Amazonia. The odour begins to appear as the flower temperature rises. This has been observed both in the field and in cultivation (for example recently Weidlich, (pers. com.) observed this by cultivating Victoria amazonica in ponds in North Carolina, and Meeuse observed the same in $V$. cruziana cultivated in Washington State (pers. com.).

The beetles are attracted by the odour and probably by the white colour of the flowers. They enter the flowers during the hours immedately following flower-opening At this stage the gynoecium appears to be receptive but no pollen is released. $V$. amazonica is an excellent example of protogyny since pollen is not released until 23 hours later. Protogyny is a feature common in primitive Magnolidae in which beetles enter the flowers, but is rarer in other subclasses of the Angiosperms. The fertile stamens are protected by the paracarpels when the beetles enter the flower. The flower temperature drops towards dawn, the fruity scent disappears gradually, and the flower re-closes. During the second day the flower remains closed and consequently the beetles are trapped for the day. The carpellary appendages in the cavity where the beetles are trapped consist of spongy swollen starchy tissue which provides food for the beetles to eat, while they are trapped inside the flower.

Also during the second day, approximately sixteen-eighteen hours after the initial opening of the flowers (i.e. about 10:00-12:00 hours), the petals gradually change colour to a dark purplish-red through the formation of anthocyanins. On the second afternoon the sepals and petals open, and in the early evening the outer staminodes of the flowers open, or are loose enough to release the beetles. Because the carpellary appendages have been eaten away by the beetles, both the stamens and the paracarpels hang loosely inwards. At this time the anthers have already dehisced and the pollen is scattered all over the stamens. The beetles become completely covered with pollen, which is in tetrads, as they push their way through the mass of stamens.

We established that the beetles emerge and fly on to another first night flower by releasing marked beetles for recapture. They choose first night flowers, as the second night flowers are no longer scented, are not heated, and are of a different colour, and by this choice they automatically cross-pollinate the new flower. The beetles are abundant and it is hard to find first day flowers without beetles. Our observations indicate that there is a sufficiently large beetle population to pollinate all the flowers.

Victoria amazonica, in the areas studied around Manaus, usually grows in large patches. Each plant continually produces flowers for a full growing season, the length of which usually depends entirely upon water depth (see Fig. 3 for variation in water level around Manaus). All the buds which are completely above the surface usually come into flower on the same day. (This was also observed by Gessner (1960)). In the areas studied around Manaus, mainly on Ilha do Careiro, V. amazo- 


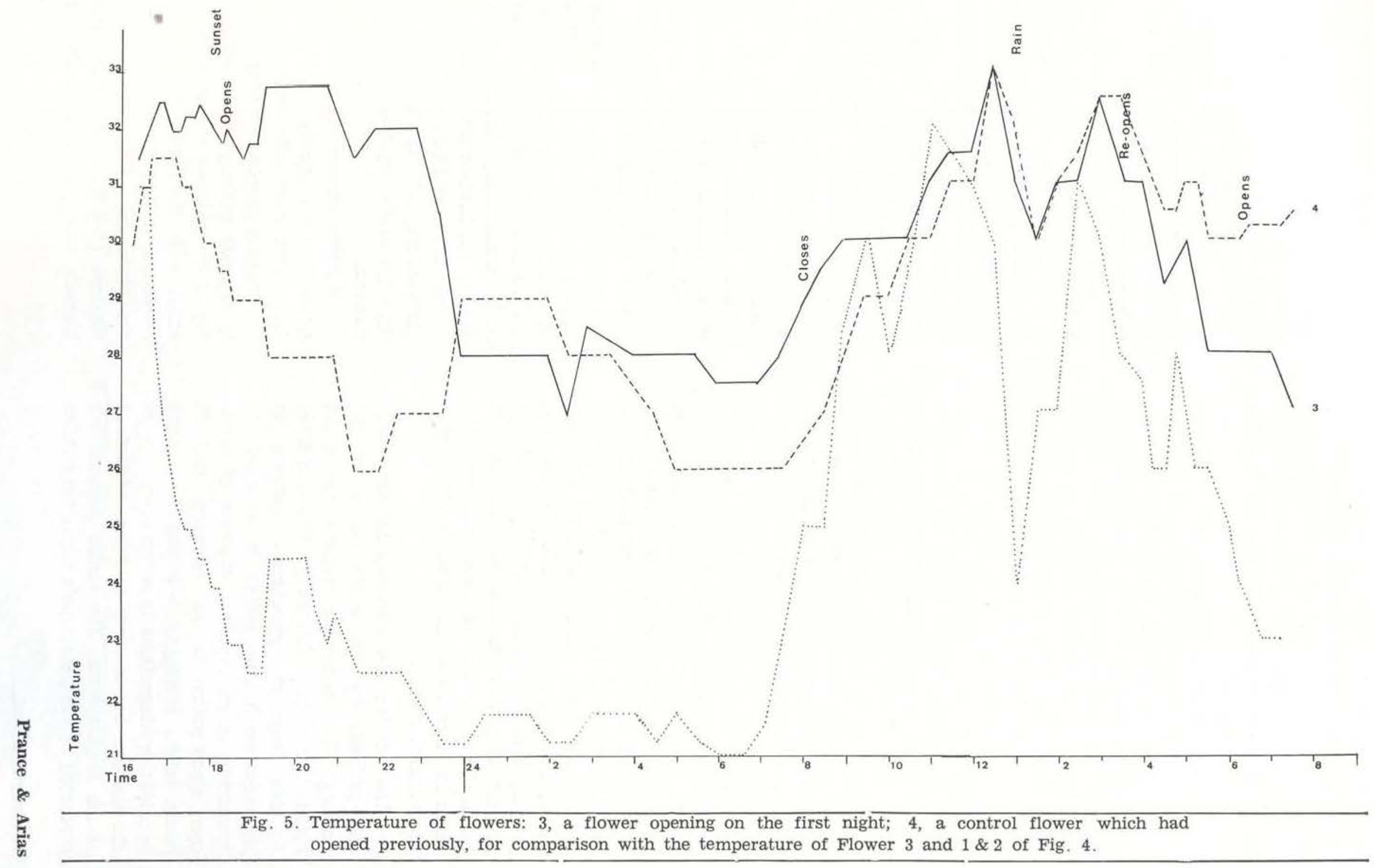


nica is abundant and grows in many lakes and flooded areas. Most of these areas are of variable water depth because of the seasonal rise and fall of the level of the Rio Amazonas. When the water depth is too high $V$. amazonica dies out.

The maximum water depth in which we found $V$. amazonica producing flowers was $5.25 \mathrm{~m}$ in the flood of July 1975 .

The question has been asked as to where the beetles feed when there is no $V$. amazonica. However, our studies over a year have shown that $V$. amazonica is in flower throughout the year because of the abundance of lakes and flooded areas at different heights, below the flood level of the river. Consequently when the river level rises and floods one area too deeply for $V$. amazonica to grow, this flooding is also filling a shallower area where the plant is flourishing. The reverse occurs as the water level falls. It was impossible to study $V$. amazonica in the same locality throughout the year, but it was always easy to find it flowering within a few kilometers at any time during the year of study. This means that the beetles are provided with flowers of $V$. amazonica throughout the year. It is of course possible that the beetles also feed on other substrates, but we have no observations on this subject.

Although many plants of $V$. amazonica live for less than a year because of changes in water level, the species is not strictly an annual. It is reported as an annual in several places because of its growth habit in cultivation in temperate regions. In Amazonia, in places where there is no change in water level, an individual plant lasts for several years. For example, a plant of $V$. amazonica presently in cultivation in the ponds of the Museu Goeldi in Belém is now 7 years old (P. B. Cavalcante, pers. com.).

\section{HABITAT OF STUDY AREA}

\section{The lake water}

The physical properties of the lakes where we studied $V$. amazonica fall well within the norms of the "white water" lakes of the area (Rai, pers. com.).

The $\mathrm{pH}$ of the waters varied from 5.05-5.70 at Santa Terezinha to 6.38 at Jacaretinga. The conductivity of these waters was found to be low, but within the normal range for this area, at $35 \mu \mathrm{Scm}^{3}$ at $20^{\circ} \mathrm{C}$. The water temperature at $42 \mathrm{~cm}$. depth during the course of our study, had a range of $2.55^{\circ} \mathrm{C}$ with a maximum tem-

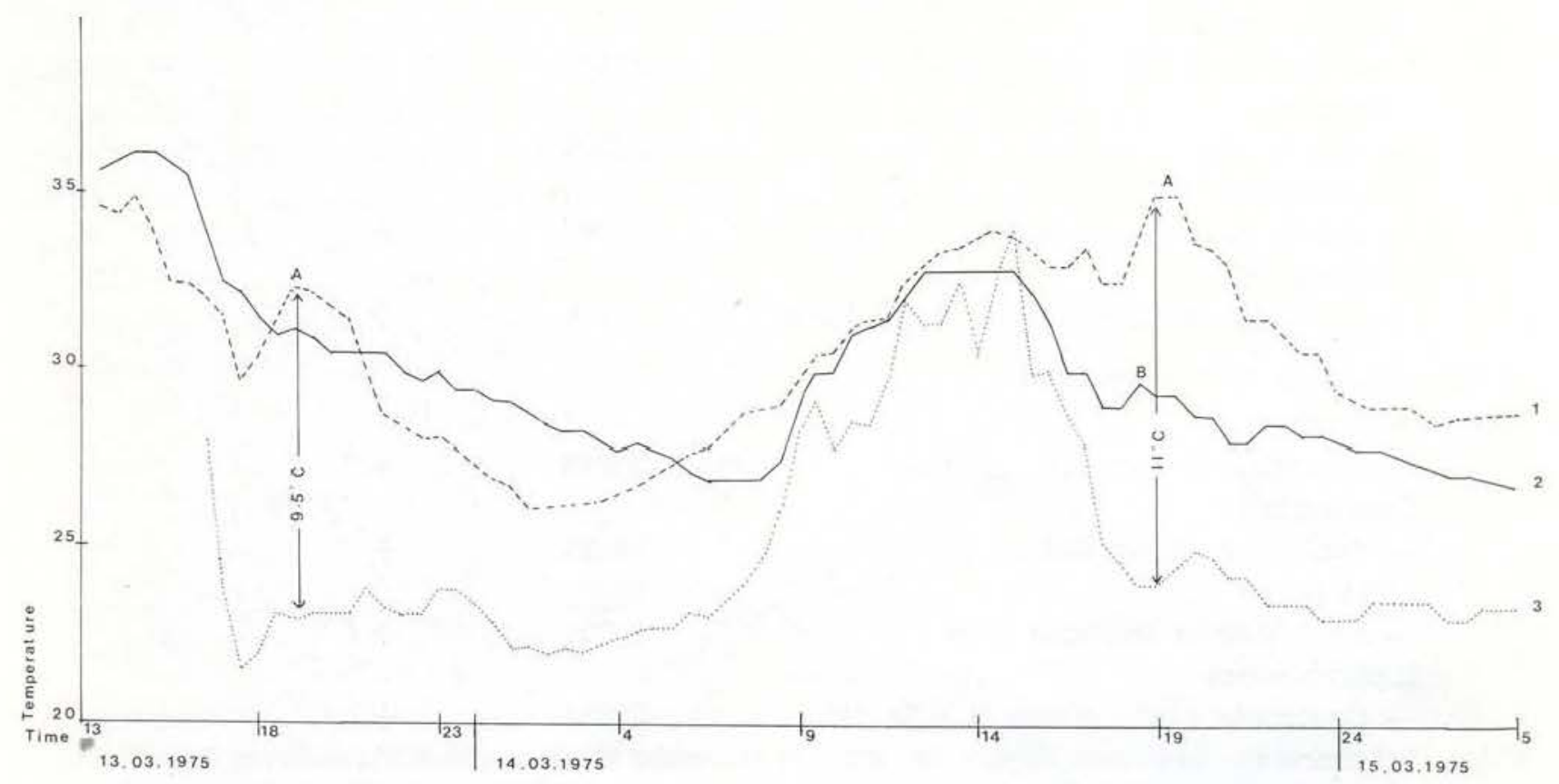

Fig. 6. Flower temperature readings made March 13-15, 1975, 1, flower opening on second evening; 2, flower opening on first evening; 3, air temperature (cf. Figs. 7 \& 8). 
perature of $28.2^{\circ} \mathrm{C}$, and a minimum of $25.65^{\circ} \mathrm{C}$. (Graph 8, curve n. ${ }^{\circ}$ ).

The oxygen content of the water was also well within the norm for the lakes of this area, with $9.2 \mathrm{mg} / \mathrm{l}$. dissolved $\mathrm{O}_{2}$ at the surface and $0.88 \mathrm{mg} / \mathrm{l}$ at the bottom. The high $\mathrm{O}_{2}$ content on the surface of the water is due to physical mixing and photosynthetic activity of plant material. The low benthic $\mathrm{O}_{2}$ concentra- tion is due to the high demand of $\mathrm{O}_{2}$ at greater depths, particularly to the decomposition of organic matter.

\section{Associated vegetation}

The vegetation of the study area was the typical pond and lake vegetation of central Amazonia. The following is a list of the plants found growing in association with $V$. amazoni$\mathrm{ca}$, in the two main localities studied:

\section{PLANTS FOUND GROWING IN ASSOCIATION WITH VICTORIA AMAZONICA}

1. Free floating aquatics

Pteridophytes

Azolla microphylla Kaulf.

Ceratopteris pterioides (Hook.) Hieron

Marsilia polycarpa Hook. \& Grev.

Salvinia auriculata Aubl.

Angiosperms: monocotyledons

Araceae

- Pistia stratiodes L.

Pontederiaceae

- Eichhornia crassipes Solms.

- Reussia rotundifolia (L.f) Castellanos

Angiosperms: dicotyledons

Euphorbiaceae

- Phyllanthus fluitans M. Arg.

Lemnaceae

- Lemna sp.

Mimosaceae

- Neptunia oleracea Lam.

Onagraceae

- Ludwigia helminthorriza (Mart.) Hara

Santa

Terezinha Jacaretinga

2. Aquatics rooted on pond

Alismataceae

- Limnocharis flava (L.) Buch.

Compositae

- Pacourina edulis Aubl.

Cyperaceae

- Fimbriostylis miliacea Vahl

Euphorbiaceae

- Caperonia castaneifolia (L.) St. Hil.

Fablaceae

Gramineae

- Panicum boliviense Hack

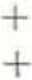

$+$

$+$

$+$

$+$

$+$

$+$

$+$

$+$

$+$

$+$

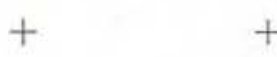

$+$

$+$

$+\quad+$

Prance \& Arias 
- Nymphaea sp.

Nymphaeaceae

Onagraceae

- Ludwigia decurrens Walt.

Sphenocleaceae

- Sphenoclea zeilanica Gaertn.

3. Growing around margin of pond

Caesalpiniaceae

- Cassia occidentalis L.

Cucurbitaceae

- Melothria fluminensis Gardner

Cyperaceae

- Cyperus mutisii (H.B.K.) Griseb.

Gramineae

- Paspalum fasciculatum Willd.

Labiatae

- Hyptis parkeri Benth.

Rubiaceae

- Diodea kuntzei K. Schum.

\section{Voucher}

Herbarium

$\begin{array}{lll}\text { No. Prance } & \text { Santa } & \\ \text { Collection } & \text { Terezinha Jacaretinga }\end{array}$

23302

23296

23280

23292

23333

23294

23293

23297

23295
$+$

$+$

The voucher number of herbarium material for the Victoria amazonica studied is Prance 22745 (INPA, NY, etc.)

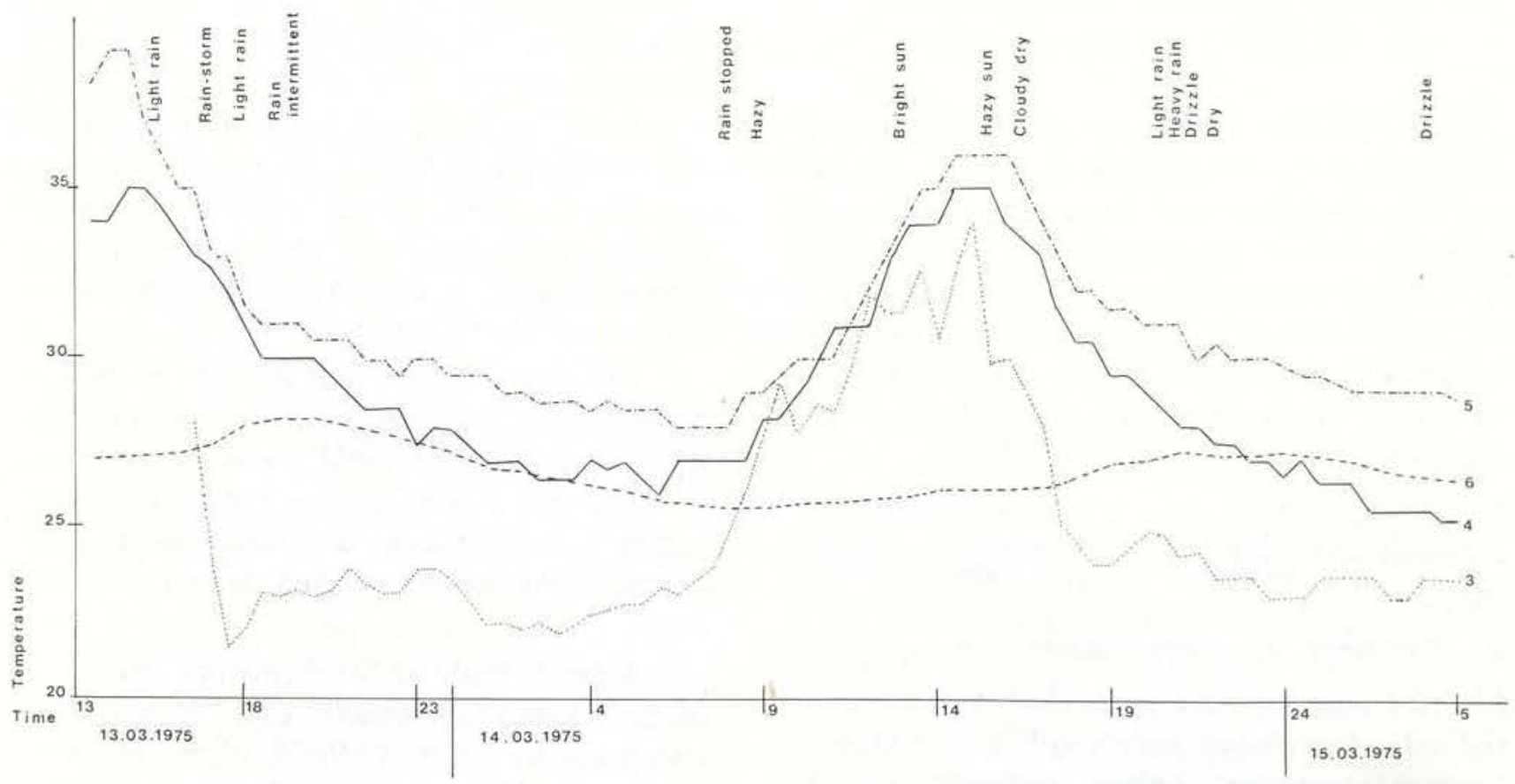

Fig. 7. Control temperature readings made March 13-15, 1975. for comparison with data of Fig. 6 \& 8 . 4 , temperature of bud which remained under water during the observation period; 5 , temperature of a leaf petiole near to the water surface; 6 , water temperature at the bottom of the lake, $42 \mathrm{~cm}$. depth; 3, air temperature. 


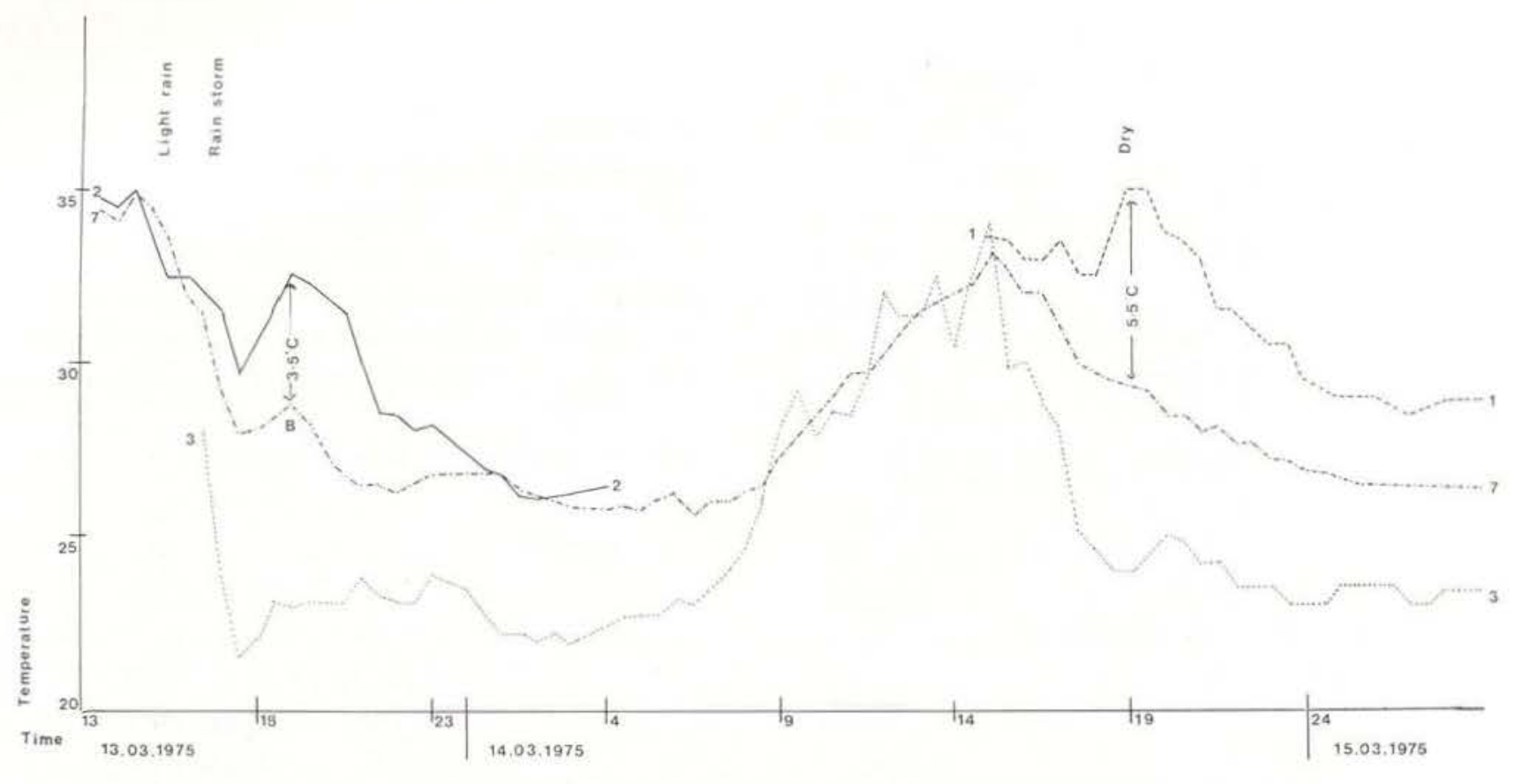

Fig. 8. Flower temperature readings made March 13-15, 1975. showing opening flowers compared with an old control flower. 1, part of curve for flower opening on second night; 2, part of curve for flower opening second night (1 \& 2 from Fig. 7); 3, air temperature; 7, flower already past first opening at beginning of observations.

\section{The OPENING AND CLOSING SEQUENCE AND COLOUR CHANGE OF THE FLOWERS}

The work of Gessner $(1960,1962)$ showed clearly that flower opening is closely correlated with light intensity. Since Gessner's work was also carried out in the vicinity of Manaus no attempt was made to duplicate it in the field. However, with the help of Dr. Ivany Válio the influence of different parts of the light spectrum was studied to investigate the mechanism involved.

1. White light (using 2 fluorescent and 2 incandescent $40 \mathrm{w}$. bulbs) inhibits flower opening.

2. Darkness stimulates flower opening .

3. Red light (created by enclosing flowers in red cellophane bags wavelength peak $623 \mathrm{~m} \mu$, for two hours just before nightfall) makes flower opening more rapid than in flowers exposed to white light.

4. Far-red light (created by enclosing flowers in red and blue cellophane bags giving a wave length peak at $750 \mathrm{~m} \mu$ for two hours just before night-fall) causes inhibition of flower opening.

From these observations of the effect of red and far-red light we can conclude that the opening movements of Victoria amazonica flowers at the time of a change from light to darkness, involve the phytochrome system in the far-red absorbing form.

The role of the phytochrome system in plant movements was described and discussed by Fondeville et al (1966) who demonstrated that the leaf-closing movements of Mimosa pudica L. at night-fall depends upon the presence of phytochrome in the far-red absorbing form.

A small study of the formation of pigment in the petals, presumably anthocyanins, was also made by Dr. Ivany Válio, after one of our field trips. Five squares of white first day petal tissue about $2 \mathrm{~cm}$. in length were placed in Petri dishes in distilled water, $2.5 \%$ dextrose and $5 \%$ dextrose respectively. One of each type of dish was placed in light, and 
another in darkness for twenty four hours. In the three dishes placed in light the petal segments all turned the same reddish-purple colour regardless of the substrate. The colour was the normal colour of second day flowers. In the petal segments kept in darkness for twenty-four hours anthocyanin synthesis occurred in all three but to a much lesser extent than in the petals kept in light. The intensity of colour was increasingly darker with a higher concentration of dextrose.

We have recorded below our observations on the opening and closing sequence, and the colour changes of flowers which occured during our investigation of flower temperature. The sequence observed for one typical flower at Santa Terezinha in February 1975, was as follows:
Time State of flower

Colour

17.00 Closed

18.00 Closed

18.12 Sepals open rapidly $1 \mathrm{~cm}$.

18.13 Sunset

18.14 Petals begin to open

18.21 Petals much more open

18.22 Open hole to centre of flower apparent

18.24 Sepals at $45 .^{\circ}$ to vertical

18.30 Sepals horizontal, petals to 45 . $^{\circ}$

First beetle enters flower

18.33 Second beetle enters flower

18.35 Third beetle enters flower

18.40 Sepals reflexed, petals over $450^{\circ}$

18.42 Fourth beetle enters flower

18.43 Fifth beetle enters flower

19.10 Sepals markedly reflexed, outer petals reach horizontal position

19.15 Central hole open enough to see beetles in centre of flower

24.00 Sepals still : reflexed, outer petals horizontal, central hole partially obscured by inner petals

1.30 Innermost petals slightly redder

3.00 Outer petals slightly above horizontal, more red colour on inner petals

5.50 Sunrise

8.00 Inner petals almost completely closed, four outer petals open, sepals open

8.30 Petals closed tighter, outer petals and sepals still open

9.00 Sepals starting to curl up

9.30 Sepals starting to curl up

12.00 Sepals curling

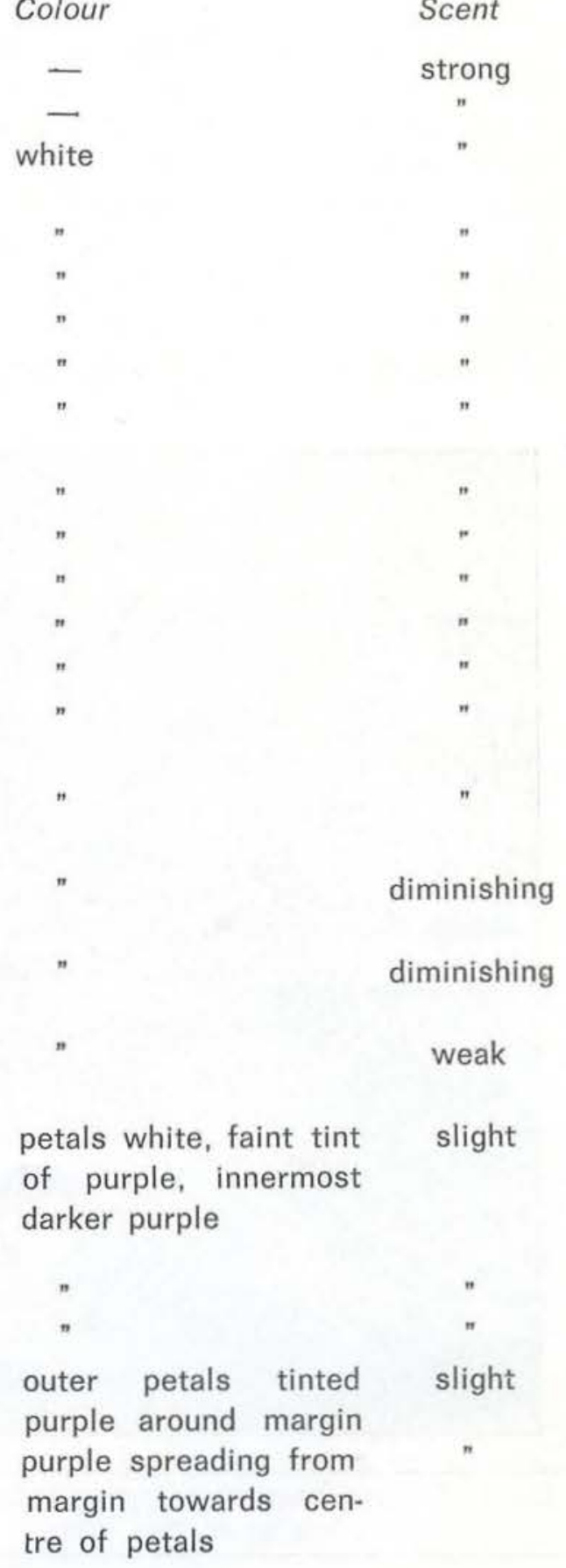


13.00 Sepals arched over, tips pressed against petals, bases remaining horizontal

15.00 Flower opening revealing $1.5 \mathrm{~cm}$. cavity in centre, but staminodes pressed tightly closed

15.10 Sepals and petals opening fast, with $6 \mathrm{~cm}$. hole in centre revealing closed staminodes

17.30 Sepals and petals open, staminodes closed

18.30 Staminodes begin to open, beetles begin to leave.

Other flowers observed showed essentially the same time sequence with minor variations depending on cloudiness, etc. When the flowers first open on the first night, on bright evenings they open unilaterally. The first sepal to open is the one on the shady side, (east), followed by those on the north and south sides. Often the west facing sepal, which faces the brighter light of the setting sun, opens 15-20 minutes later than the other three. One evening when it was very dark and stormy towards the west, but much brighter towards the east, all the west facing sepals opened first because light intensity was greater ( $2 \mathrm{f}$ stops on an exposure meter) in the opposite direction from the setting sun. The close synchronization of flower opening in any patch of $V$. amazonica is impressive.

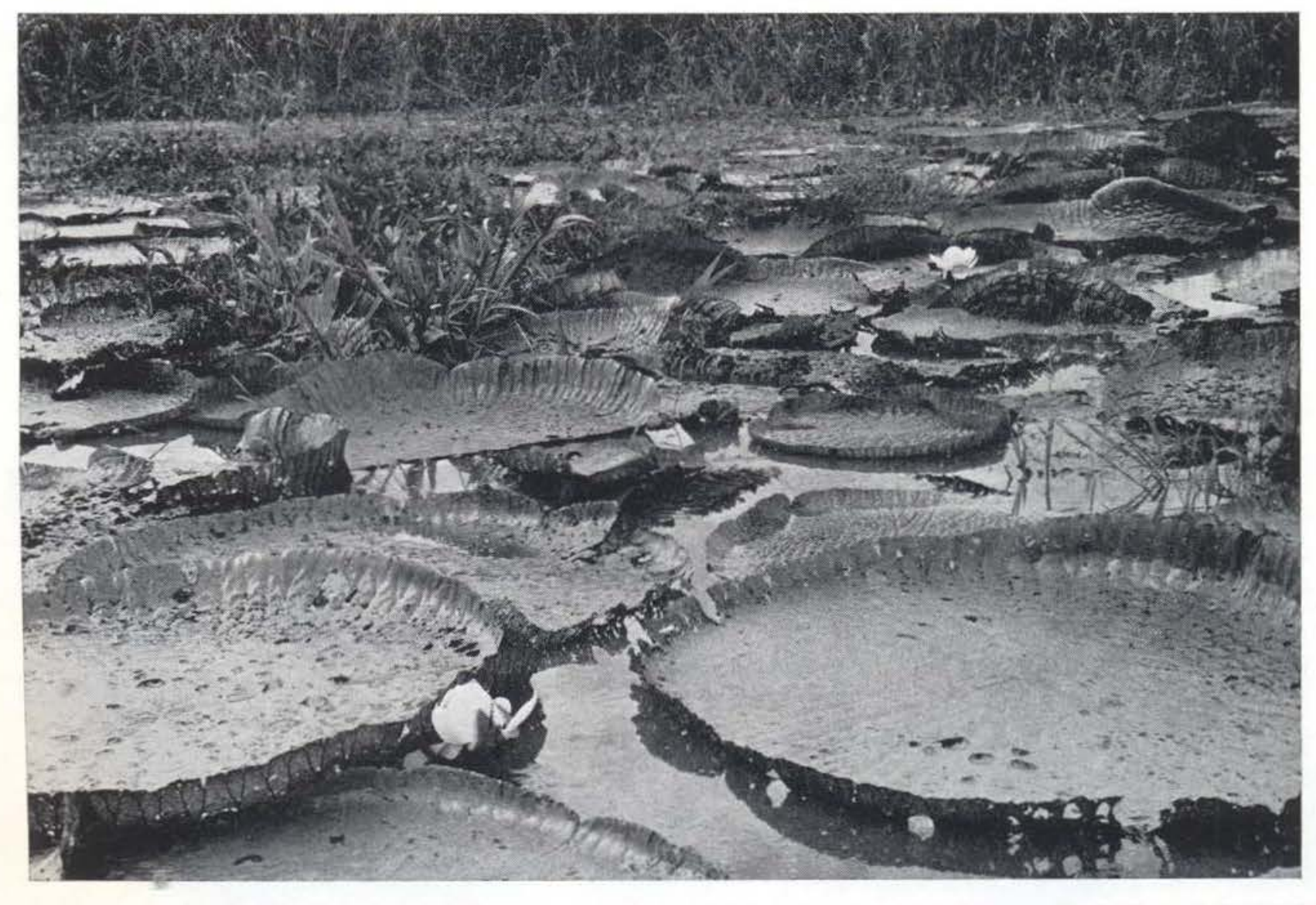

Fig. 9. Victoria amazonica (Poepp.) Sowerby, growing in study area at Santa Terezinha, Ilha do Careiro, the locality of Figs. 10-20. 
All flower buds appear to open on the first day that they are entirely above water level. The buds tend to be partially submerged for one or two days after they first appear above water level, with the receptacle still submerged. By the second or third day they are clear of the water, sometimes by as much as $10 \mathrm{~cm}$., and then they open. In rather deep water, where conditions are beyond optimum depth, the flowers often open with the lower part of the receptacle still partially submerged.

When the purple flowers open on the second day, the petals and sepals open early in the afternoon while the light is still bright, around 15.00 hours. The staminodes remain itightly closed until after 18.00 hours, when they either open, or are loose enough for the beetles to push their way easily through the central cavity.

\section{FLOWER TEMPERATURE}

In the introduction we have pointed out that flower temperature observations have been made in cultivated plants of Victoria since Planchon (1850), and that they are still being made today (Weidlich, pers, com.; Meeuse, pers. com.). However, even in the detailed field study of Valla and Cirino (1972) flowers of Victoria cruziana were taken into the laboratory for temperature measurements; we have, therefore, tried to make all our temperature readings under natural conditions in the field. Readings were taken with ordinary mercury thermometers by making a hole with a cork-borer into the central cavity in the region of the carpellary appendages. (See Fig. 13-14).

The graphs (Fig. 4-5) show the results for four sample flowers from Santa Terezinha, Ilha do Careiro. Fig. 4-5 were made from data collected on the same days.

Readings for Flowers 1,2 and 3 began just before the first opening. Flower 4 was a control flower which was only partially above water, and which opened on the second day of the observations. Readings on Flowers 1,2 and 3 continued on the second day to act as controls for Flower 4 when it was opening.
The similarity in the behaviour of four flowers observed is immediately apparent. Since Flowers 1,2 and 3 behaved similarly at the same time they will be discussed together.

Table 1. Summary of the temperature changes of the 4 flowers of Fig. 4-5.

Temperature Readings

\begin{tabular}{|c|c|c|c|c|}
\hline & $\begin{array}{c}16: 30 \\
\text { hours }\end{array}$ & $\begin{array}{l}17: 00 \\
\text { hours }\end{array}$ & $\begin{array}{c}20: 00 \\
\text { hours }\end{array}$ & $\begin{array}{c}23: 00 \\
\text { hours }\end{array}$ \\
\hline Air & $31^{\circ} \mathrm{C}$ & $27^{\circ} \mathrm{C}$ & $24.5^{\circ} \mathrm{C}$ & $21.5^{\circ} \mathrm{C}$ \\
\hline Flower 1 & $30^{\circ} \mathrm{C}$ & $30^{\circ} \mathrm{C}$ & $32.5^{\circ} \mathrm{C}$ & $31.0^{\circ} \mathrm{C}$ \\
\hline Flower 2 & $31^{\circ} \mathrm{C}$ & $32^{\circ} \mathrm{C}$ & $33^{\circ} \mathrm{C}$ & $31.0^{\circ} \mathrm{C}$ \\
\hline Flower 3 & $31.5^{\circ} \mathrm{C}$ & $32.5^{\circ} \mathrm{C}$ & $32.75^{\circ} \mathrm{C}$ & $32^{\circ} \mathrm{C}$ \\
\hline $\begin{array}{l}\text { Control } \\
\text { Flower } 4\end{array}$ & $30^{\circ} \mathrm{C}$ & $31.5^{\circ} \mathrm{C}$ & $28^{\circ} \mathrm{C}$ & $27^{\circ} \mathrm{C}$ \\
\hline
\end{tabular}

The readings began at 16:30 hours on the first day when Flowers 1,2 and 3 were buds, which were ready to open that day. At that time of day, there was no significant difference beiween air and flower temperature. However, as air temperature continued to drop the flower temperature rose (Table 1).

From 17:00 hours onwards the flowers smelled strongly, and the difference between air and flower temperature continued to increase until about 20:00 hours, that is for about one and a half hours after the flowers had first opened (Table 1).

The maximum difference between flower and air temperature was registered between 22:00 and 23:00 hours. When the flower temperature began to drop at 23:00 hours, the air temperature was 21.5 and Flower 3 registered $32^{\circ}$, a difference of $9.5^{\circ} \mathrm{C}$. At the same time Control Flower 4 was $27^{\circ}$, or five degrees lower than the open flowers, and $4.5^{\circ}$ above the ambient temperature (Table 1).

The maximum difference between flower bud temperature and the other flowers was between 20:00 and 23:00 hours, almost the same time period at which the maximum flower-air temperature difference appeared. 


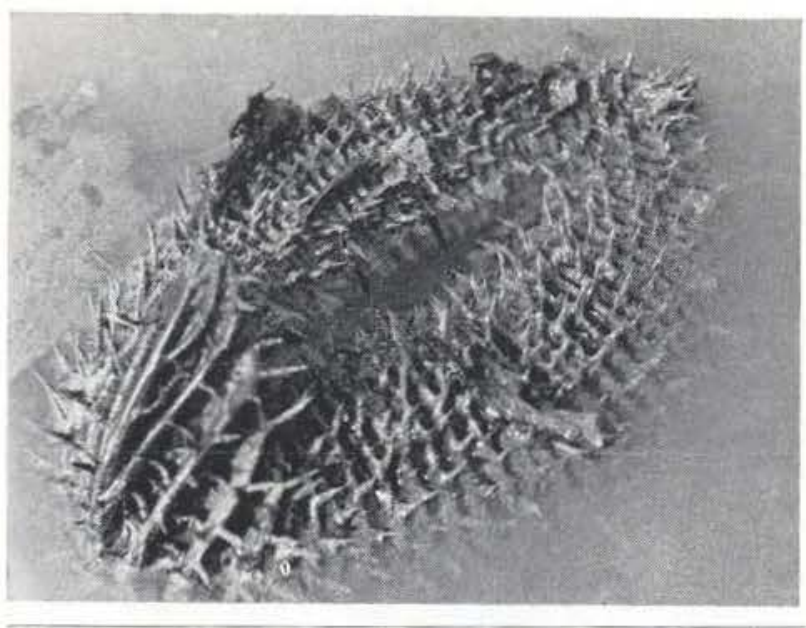

Fig. 10. Young leaf of V. amazonica as it emerges.

This further supports the hypothesis that the elevated temperature is due to metabolic activity within the opening flowers.

The difference of $4.5^{\prime} \mathrm{C}$ between the Control Flower 4 and the ambient could be due partially to insulation within the centre of the flower which is sheltered from wind and other influences; but it is probable that is also partially due to some lower rate metabolic activity which occurs in the unopened flower. The insulation within the flowers was demonstrated the next day when it rained at 12:45 hours and ambient temperature dropped more than flower temperature. Also in the afternoon there was a $2^{\circ}$ temperature difference between the air temperature and that of old pollinated scentless flowers. A certain amount of metabolic activity in the control flower is indicated by the fact that its temperature rose between 22:00 and 24:00 hours. Between 24:00 hours and 2:00 hours of the (following day) the Control Flower actually had a slightly higher temperature than Flowers 1 and 3 , and the same temperature as Flower 2. After that short burst of metabolic activity Control Flower 4 remained slightly below the temperature of the other flowers until the next afternoon. The graphs show that after 09:00 hours the differences between air and flower temperature are not significant.

The insulating effect of the flower interior means that the significant temperature diffe- rence between the air and flower is slightly less than the difference measured, perhaps about $2^{\circ} \mathrm{C}$. Therefore, the $9.5^{\circ}$ maximum difierence between the air and the flower temperature probably reflects approximately $7^{\circ} \mathrm{C}$ due to metabolic activity.

On the second afternoon, over twenty four hours after the first reading. Flower 4 was the only active flower ready to open. From 18:00 hours the Flower 4 temperature was significantly higher than the air temperature, and the temperature of Flowers 1,2 and 3 which were active on the previous night.

The graphs of Fig. 6-8 present the results of temperature readings at another time, March 13-15, 1975, which show essentially the same results as those discussed above, but with more controls and at a time when the weather conditions were much more variable. They ranged from bright sunshine to a storm with heavy rain and high winds. It can be seen (Fig. 7) that the weather changes did not alter the basic temperature cycle of the flowers of $V$. amazonica. The rain is recorded on Fig. 7, but also applies to Fig. 6-8.

Fig. 6 shows air temperature (3), a flower opening on the second evening (1), and a flower opening on the first evening (2). In both cases the active flower temperature was elevated well above air temperature; $9.5^{\circ}$ on the first evening and $11^{\circ} \mathrm{C}$ on the second evening for the other flowers. Fig. 8 shows the early evening temperatures of the same flo-

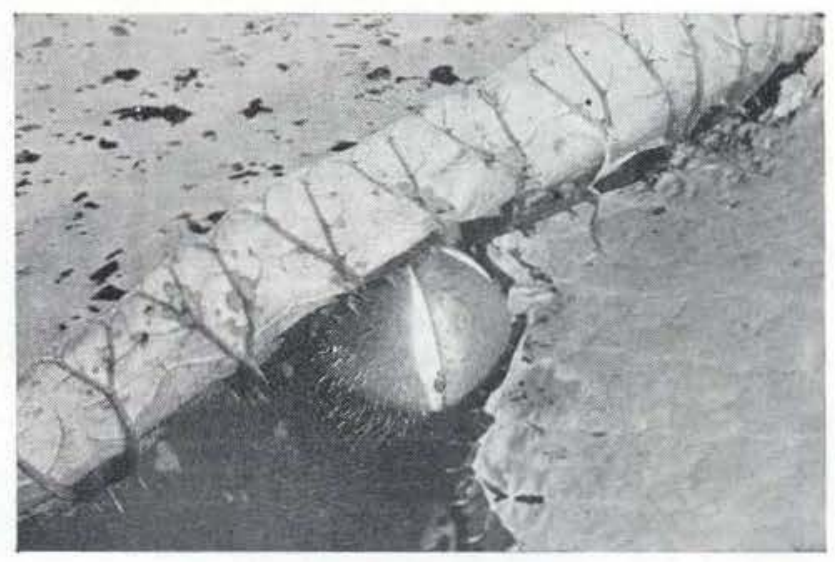

Fig. 11. Bud of V. amazonica on the day before opening. 
wers plotted against an old control flower (7) to demonstrate the insulation effect of the flower. In this case the maximum difference between an opening flower, and the old flower was $3.5^{\circ}$ on the first (rainy) night and $5.5^{\circ} \mathrm{C}$ on the second (dry) night. We feel that these differences reflect more accurately the temperature difference due to metabolic activity. Fig. 7 shows the other control readings that were made parallel with temperature readings of the active flowers. Curve 4 is the temperature of a bud which remained underwater throughout the study, and Curve 5 is of the temperature of a leaf petiole near the water surface. These two curves are similar and reflect the changes in temperature of the water surface due to the various climate and time factors. Curve 6 is the temperature of the water at the bottom of the lake among the rhizomes of $V$. amazonica (water depth of $42 \mathrm{~cm}$ ).
The two places marked B on Graphs 6 and 8 are interesting, since both show a slight temperature rise in the evening in old (second day) flowers. In Fig. 6 the rise (B) is shown in the flower which opened previously on the first day of study, and in Fig. 8 the rise (B) is shown in a second day flower selected as a control. This small temperature rise (up to $1^{\circ} \mathrm{C}$ ) reflects increased metabolic activity in the early evening at about the time the staminodes open up to release the beetles.

\section{EMISSION OF ODOUR}

The strong fruity scent of the flowers has already been mentioned in the general discussion, and in the discussion of the time sequence. In order to investigate the floral parts emitting the scent we used the neutral red method described by Vogel (1962: 728-729), and also used by Valla and Cirino (1972) in

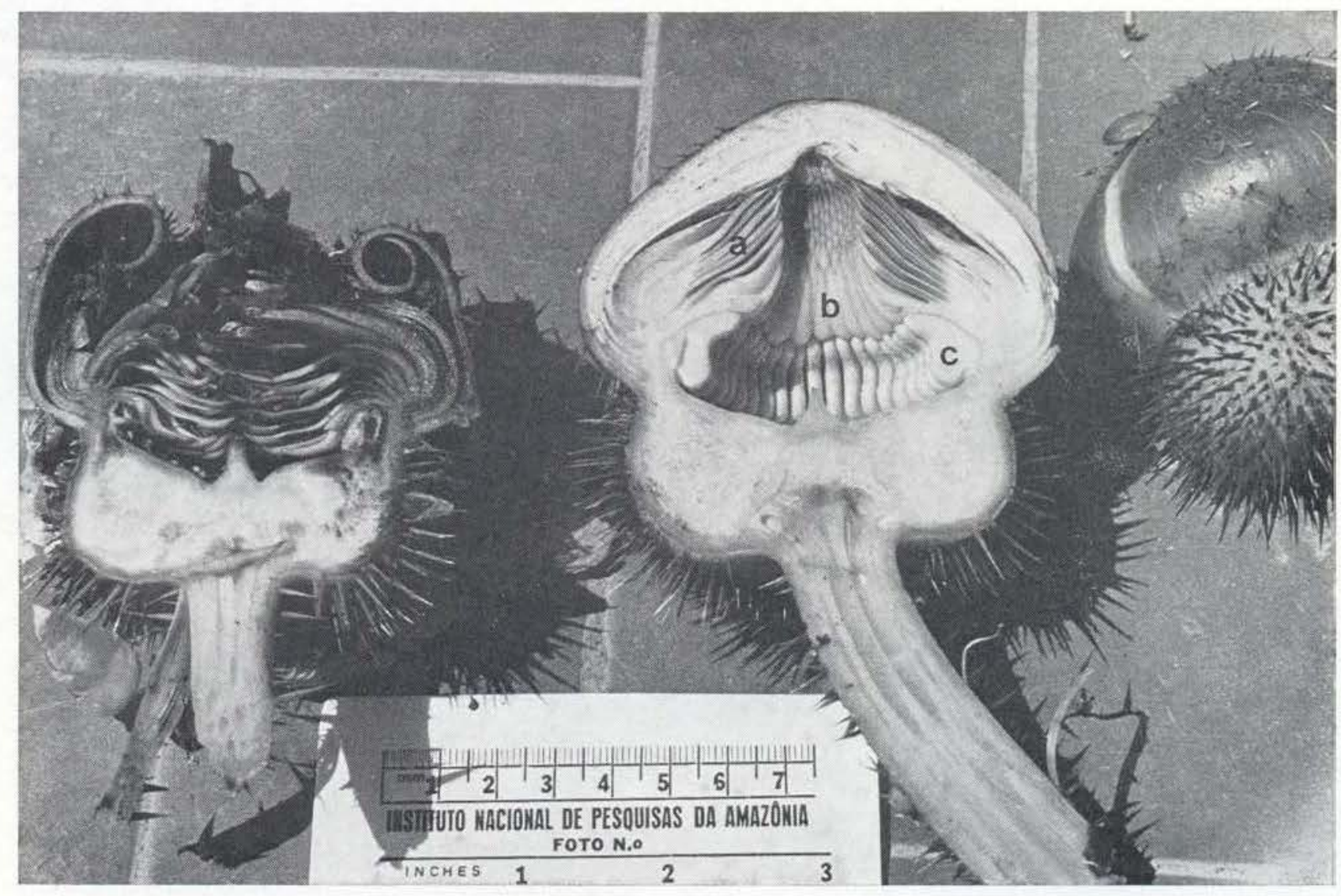

Fig. 12. Half flowers. Left, old flower already visited by beetles and ready to submerge. Centre, flower bud; a, fertile stamens; b, paracarpels; c, carpellary appendages. Right, exterior of flower bud. 
their work on Victoria cruziana. With this technique flowers are submerged in a $1: 10,000$ solution of neutral red in slightly acid distilled water for one hour. We used flowers which had just opened at 18.00 hours, the time of maximum odour.

Our results for $V$. amazonica are very similar to those of Valla and Cirino for V. cruziana. The sepals did not stain at all, but the petals all stained with an increasing intensity towards the interior. The outermost petals were hardly stained at all, the second circle had dark red streaks towards the base of the inside, and the smaller innermost circle of petals was stained dark reddish-purple over the entire petal surface. Both the stain and the olfactory tests indicated that the petals as well as the interior of the flowers, emit the scent, which may explain why the beetles linger in the petals, before entering the flowers. The staminodes and stamens were not stained significantly by the neutral red. The paracarpels did not take up the stain, but the top of the disc stained an extremely dark red. This disc tissue was found to smell very strongly and emit much more odour than the paracarpels.

\section{CHEMICAL CONTENTS OF THE CARPELLARY APPENDAGES}

No original work was done by us on the chemistry of the carpellary appendages since much has already been published, especially by Knoch (1899). Knoch studied the changes in chemical composition of the appendages which occur during the flowering period. He related this to the liberation of heat and carbon-dioxide.

This tissue is rich in carbohydrates, as would be expected as its primary function is feeding the beetles. Knoch's data show that the appendages contain $28.47 \%$ dry weight of starch, and $5 \%$ dextrose, at the initiation of anthesis (data from Knoch 1899, first experiment p. 47,49).

The only chemical tests that we made were to confirm the presence of starch and dextrose in the carpellary appendages. Meeuse (pers. comm.) reports the presence of starch phosphorylase in the appendages of V. cruziana.

\section{THE BEETLES}

Various authors have reported the presence of beetles in the flowers of Victoria. In fact the beetles were observed by Robert Schomburgk (1837) who collected the plants that led to the description of the genus Victoria. Schomburgk's original field description said "the flower is much injured by a beetle (Trichius "spec".) which destroys completely the inner part of the disk; we have counted sometimes from 20-30 in one flower".

The only species of beetle reported previously in the flowers of Victoria amazonica is Cyclocephala castanea Olivier (Scarabaeidae: Dynastinae); for example, Princess Tereza of Bavaria (1897) and Gessner (1962) reported C. castanea in the flowers of V. amazonica. We have found only 3 male specimens of C. castanea in the Manaus area. This species has been reported previously from Barroso Island, Careiro, near Manaus (Hardy, pers. com.). The most common species of beetle in the area which we have studied, is a new species, C. hardyi Endrödi, which is being described from our collections by Dr. Sebo Endrödi, (in press), who monographed the genus Cyclocephala in 1966.

Since $C$. hardyi is very similar to $C$. castanea in its external morphology, it is probable that many of the previous reports refering to C. castanea in flowers of Victoria in the Manaus area may have been based on the presence of $C$. hardyi. We have found large numbers of $C$. hardyi in the flowers of $V$. amazonica throughout the year, and we think it to be the principal pollinator of $V$. amazonica around Manaus. The frequency of this beetle varied considerably from flower to flower and from locality to locality. Table 2 gives some sample data of beetle collections

Another species which we found in $V$. amazonica was Cyclocephala verticalis Burmeister, which occurred frequently during the months of August, September and October. but was not found from November to Februa- 

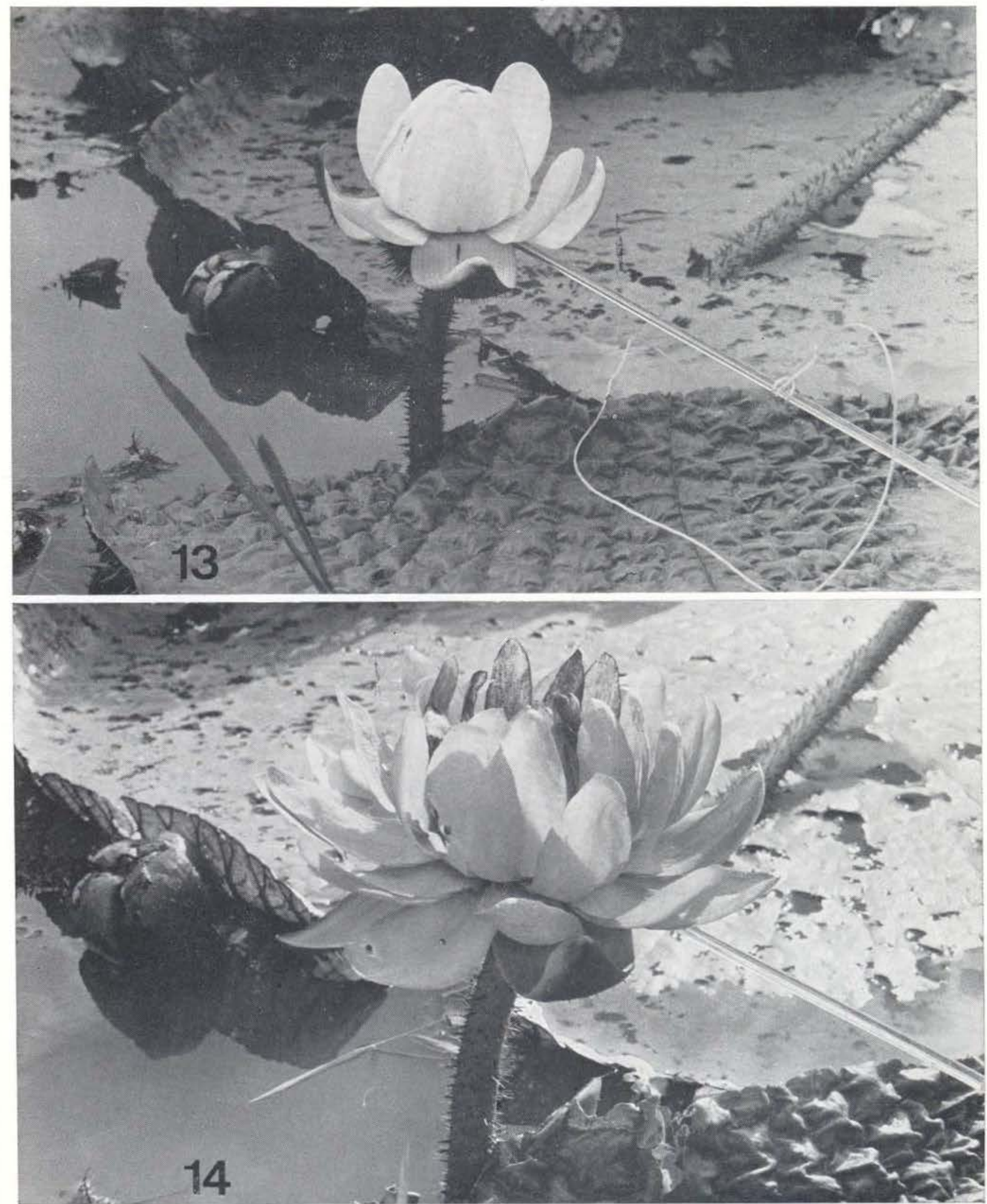

Fig. 13. V. amazonica flower in early morning of second day (7.00) while still white. Fig. 14. V. amazonfca same flower as Fig. 13 at 17.00 , with corolla purple. 
ry. C. verticalis re-appeared in the middle of March and it occurred until the end of July at the conclusion of our study. This species is probably a secondary pollinator of $V$. amazoni$c a$ in the Manaus area.

A fourth species of scarab beetle, Ligyrus similis Endrödi, was found in two flowers of $V$. amazonica during the months of February and March. This species was found alone in one flower, but in another it occurred together with twenty-three individuals of $C$. hardyi. $L$. similis appears to be a casual visitor, and it is not important as a regular pollinator of $V$. amazonica in the vicinity of Manaus. The description of this beetle was published by Endrödi
(1968). It was previously known from Venezuela, Trinidad, Suriname, Ecuador \& Peru, but was unknown from Brazil (Endrödi 1969).

In contrast to the abundance of scarab beetles in the area of our study, Valla and $\mathrm{Ci}$ rino (1972) found a single scarab beetle in the flowers of $V$. cruziana in their field work in Argentina. The beetle was a species of Chalepides, also in the Cyclocephalinae.

Differentiation between the 4 species of beetles by their external morphology is easy except in the case $C$. hardyi and $C$. castanea. A summary of some of the external differences is given in Table 2.

Table 2. Differences between beetles, based on external morphology.

\begin{tabular}{l|l|l|c}
\hline \multicolumn{1}{c|}{ Character } & C. hardyi/castanea & C. verticalis & L. similis \\
\hline External colour & $\begin{array}{l}\text { dark brown pronotum, } \\
\text { lighter brown elytra }\end{array}$ & $\begin{array}{l}\text { lighter brown, the } \\
\text { elytra slightly lighter } \\
\text { than the pronotum }\end{array}$ & Black \\
Length & $2.2-2.5 \mathrm{~cm}$ & $1.2-1.3 \mathrm{~cm}$ \\
Width & $1.1-1.2 \mathrm{~cm}$ & $0.6-0.7 \mathrm{~cm}$ & $2.1-2.3 \mathrm{~cm}$ \\
$1.2-1.3 \mathrm{~cm}$
\end{tabular}

The difference between C. castanea and $\mathbf{c}$. hardyi is in the male genitalia and the beetles must be dissected to identify them. The male genitalia of both species are illustrated in Fig. 21.

Table 3. Sample of occurrence of beetles in individual flowers of $\mathbf{V}$. amazonica Locality: Careiro

C. hardyi

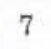

5

0

4

4

C. verticalis
0
0
1
0
0

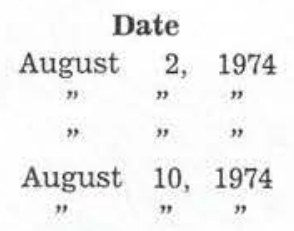

Locality: Igapó Canteiro, Ilha do Careiro

C. hardyi

$\begin{array}{rl}5 & 0 \\ 5 & 0 \\ 12 & 0 \\ 4 & 2 \\ 21 & 0 \\ 5 & 0 \\ 5 & 1 \\ 0 & 0 \\ & 1\end{array}$

Date

$\begin{array}{ccc}\text { August } & 22, & 1974 \\ " & " & " \\ " & " & " \\ " & " & " \\ " & " & " \\ " & " & " \\ " & " & \end{array}$

C. hardyi

2

5

0

7
C. verticalis

0
0
1
5

C. verticalis

1

1

1

1

0

0

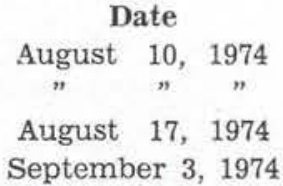


Locality: Santa Terezinha, Ilha do Careiro

\begin{tabular}{|c|c|c|c|c|}
\hline C. hardyi & C. verticalis & & ate & \\
\hline 0 & 2 & August & 22 , & 1974 \\
\hline 11 & 0 & $n$ & $"$ & " \\
\hline 1 & 0 & $"$ & $"$ & $"$ \\
\hline 0 & 1 & $n$ & $"$ & $n$ \\
\hline
\end{tabular}

Locality: Santa Terezinha, Ilha do Careiro

C. hardyi

C. verticalis

October 4, 1974

0
16

2
0
1
0
0
0
0
0
0

Locality: Santa Terezinha, Ilha do Careiro

\section{C. hardyi}

4
2
4
8
5
4
3
2

Locaiity: Jacaretinga

C. verticalis

$\begin{array}{cccc}0 & \text { January } & 14, & 1975 \\ 0 & " & " & " \\ 0 & " & " & " \\ 0 & \text { February } & 8, & 1975 \\ 0 & " & " & " \\ 0 & " & " & " \\ 0 & " & " & " \\ 0 & " & " & "\end{array}$

C. hardyi

9
6
8
0
4

C. hardyi

13
14
17
17
16
26
14
14

C. hardyi

5
7
8
26
13
11
6
1

Date August 22, 1974

$\begin{array}{cccc}0 & \text { August } & 22, & 1974 \\ 0 & " & " & " \\ 0 & " & " & " \\ 1 & " & n & " \\ 0 & n & "\end{array}$

C. verticalis

Date

February 20, 1975

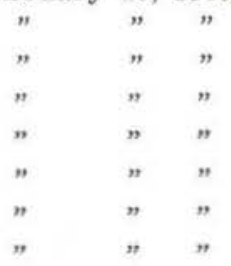

\section{Date}

February 20, 1975



0
0
0
0
0
0
0
0

C. verticalis

\begin{tabular}{|c|c|c|c|}
\hline 0 & February & 20 & 1975 \\
\hline 0 & $"$ & $"$ & $"$ \\
\hline 0 & $"$ & $"$ & $"$ \\
\hline 0 & $"$ & $"$ & $n$ \\
\hline 0 & $n$ & $"$ & $"$ \\
\hline 0 & $"$ & $"$ & $"$ \\
\hline 0 & $n$ & $"$ & $"$ \\
\hline 0 & $"$ & " & $"$ \\
\hline
\end{tabular}

C. hardyi

C. verticalis

3
2
4
12

Locality: Santa Terezinha, Ilha do Careiro
Date March 7, 1975 n " n,
C. verticalis

\begin{tabular}{|c|c|c|c|c|}
\hline 1 & 0 & March & 13-14, & 1975 \\
\hline 15 & 0 & $"$ & $"$ & $"$ \\
\hline 1 & 0 & $"$ & $"$ & $"$ \\
\hline 6 & 0 & $"$ & $"$ & $"$ \\
\hline 17 & 0 & $"$ & $"$ & " \\
\hline 20 & 0 & $n$ & $"$ & $"$ \\
\hline $23^{b}$ & 0 & $\eta$ & $"$ & $"$ \\
\hline 12 & 0 & $"$ & $"$ & , \\
\hline 11 & 0 & $"$ & $"$ & $"$ \\
\hline 23 & 0 & $"$ & $"$ & \\
\hline 12 & 0 & $"$ & $"$ & $"$ \\
\hline 17 & 0 & $"$ & $"$ & $"$ \\
\hline 24 & 0 & $"$ & $"$ & $"$ \\
\hline 11 & 0 & $"$ & $"$ & $"$ \\
\hline 23 & 0 & $"$ & $"$ & " \\
\hline
\end{tabular}

C. hardyi

9
2
5
2

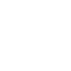


Locality: Santa Terezinha, Ilha do Careiro

C. hardyi

15

9

13

18

9

9

25

9

15

14

c. These ccunts of C. hardyi for Morch 13-14 include the three specimens of C. castanea which we found.

b. Cne specimen of Ligyrus similis found in this flower

c. Moximum number found in one flower.

To confirm the pollinating role of the beetles, we collected them as they emerged from the second day flowers. It was found that beetles emerged completely covered with pollen. It adhered to the entire body surface of the beetles because they were covered with a sticky floral secretion, resulting from burrowing and eating in the central cavity of the flower. After their twenty-four hours of captivity, the sticky beetles emerged, brushing past the mature stamens, and collecting the dry pollen.

After they emerged from the flower, the beetles were observed resting momentarily on the petals and outer staminodes. Then they flew directly to a new (first night) flower. Beetles collected from flowers and marked with paint on the elytra were released at dusk from three points; old flowers, V. amazonica leaf pads, and holding cages. They were observed to fly directly from the release point to the new (first night) flowers. (See Table 4 for data on marked beetles). Low recovery counts, and small amounts of paint on recovered beetles showed us that most of the paint had rubbed off the insects while they were within the flowers. The second group of

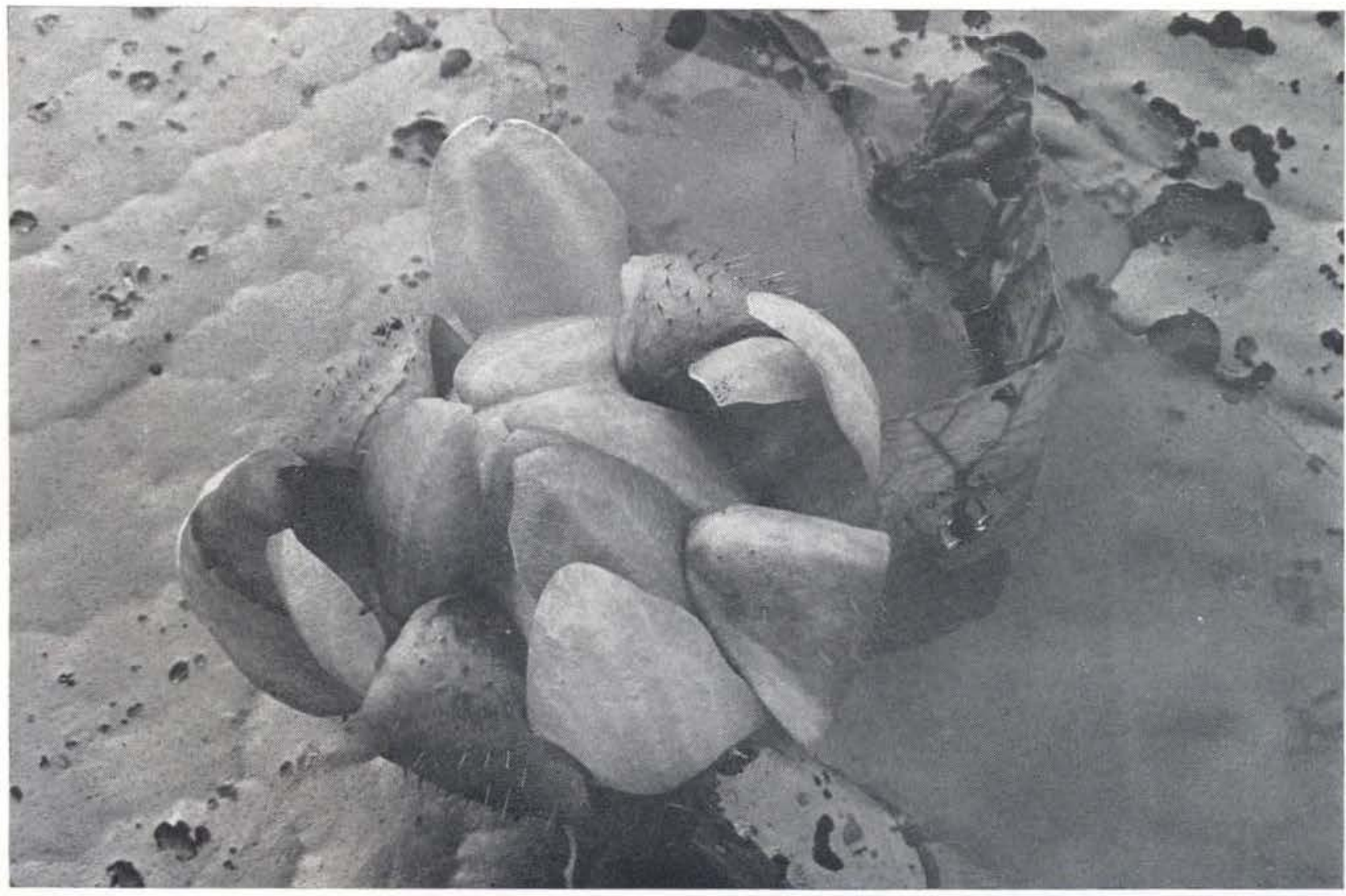

Fig. 15. Old third day flower of V. amazonica, gradually sinking into water. 
beetles were marked by removing their hind tibia and tarsi. Recovery counts were much nigher. (See Table 4). The beetles approached a white flower, circled the flower and then landed on the petals. When they landed, the beetles entered the flower immediately.

On one occasion a beetle which was released early, before the new (first aight) flowers opened, was observed circling a heavily scented bud. It landed on the bud and forced its way into the flower, giving support to the idea that the scent of the flowers is an important attractant.

The data for March 13, 1975 was collected from the release of 80 marked beetles of which 22 were recaptured making a total of $27.5 \%$ recaptured.

Beetle flight activity corresponded with the time of flower opening. Beetles which were released before dusk, remained on the ground until the light faded and the flowers began to open. At 18:00 hours, the beetles began to fly, but usually they flew for short distances only, and landed on nearby vegetation. The beetles are most active in flying between 18:30 and 19:00 hours. In our releasing experiment all the beetles had left the release point by 19:00 hours. Although the greatest flight activity among the beetles was early in the evening, beetles were observed entering the first night flowers and flying about the pond until almost midnight.

The number of beetles in flowers depends on flower size. In the case where our maximum of forty seven beetles were found in a single flower, the flower was very large. There was extensive damage to the receptacle caused by the large number of beetles. In fact often when there are many beetles in one flower, the interior chamber is completely occupied with beetles, and often one or more can still be seen in the tunnel formed by the stamens and paracarpels.

In about $70 \%$ of the flowers examined there were 1.5 cylindrical holes into the gynoecium made by the beetles. The holes began in the central cavity where the beetles were trapped, and were bored directly towards the outside of the gynoecium, but they were rarely long enough to reach the outermost tissue of the gynoecium, or the water. The direction of the holes towards the exterior of the gynoecium meant that they caused comparatively light damage to the ovules and had little influence on seed-set. The boring of holes into the gynoecium appeared to be an attempt by the beetles to escape rather than part of their regular feeding habit.

Table 4. Data on recapture of marked beetles (Cyclocephala hardyi).

Date

Flower n ॰ $^{\circ}$

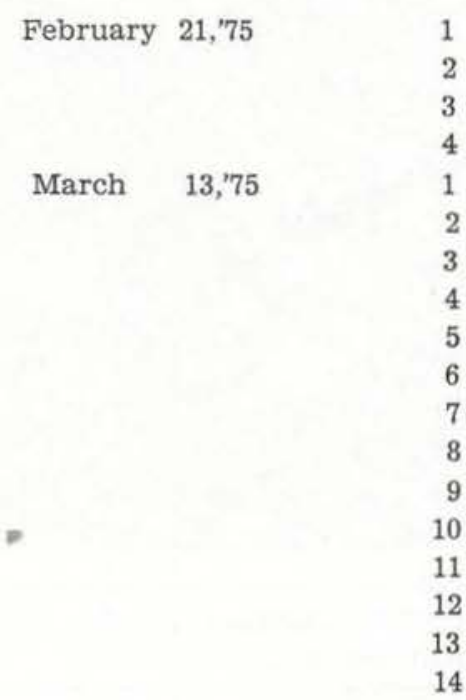

\section{N.० of beetles \\ in flowers}

13
11
6
1
12
10
16
16
15
10
17
6
7
31
34
17
47
17

\section{N.॰ of marked}

Beetles

2

0

0

0

2

4

2

2

4

0

5

0

1

1

0

0

0
Distance from release point

5-30 meters

10-40 meters

200-250 meters

A study of Floral... 


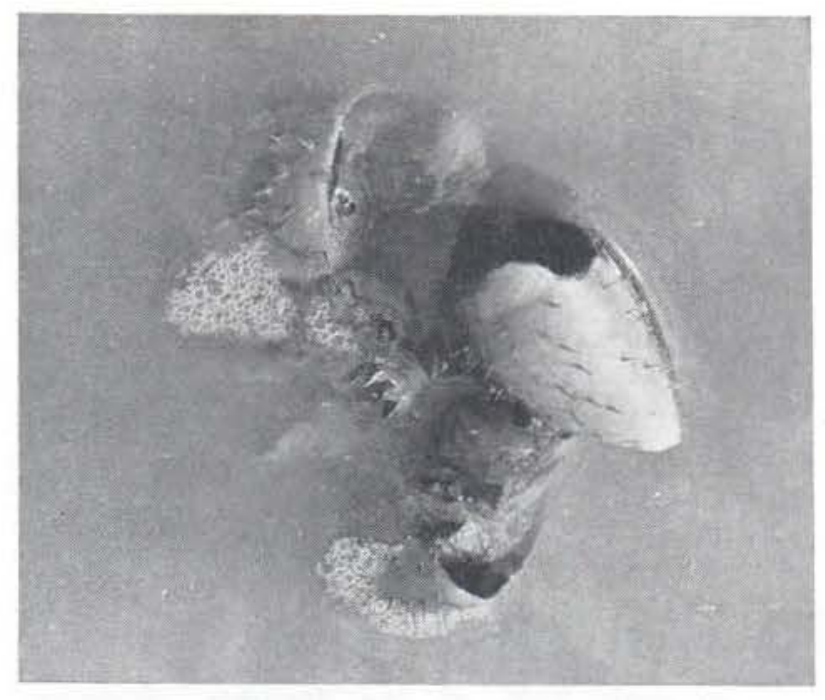

Fig. 16. Old fertilized flower of V. amazonica already becoming submerged for the fruit to develop underwater.

We seldom found the paracarpels damaged by beetles. The carpellary appendages provide food tissue, and the paracarpels provide protection for the fertile stamens. Flowers examined after the beetles have left show that the carpellary appendages are almost entirely eaten away by the beetles. The flowers are warm and the beetles are comfortable feeding on the appendages during their enforced stay inside. The amount of damage done to the flower by the beetles is directly proportional to the number and species of beetles present. Those flowers with many beetles (over 20 per flower) show a great amount of damage to the gynoecium with up to 4 or 5 cylindrical holes of $2 \mathrm{~cm}$. diameter bored into the gynoecium. In flowers with few beetles, (3 to 4 of $C$. hardyi) there is usually no gynoecium damage, but the carpellary appendages are completely eaten. Of the more than 500 flowers examined only $8 \%$ were undamaged by beetles, and in the areas studied about $94 \%$ of the flowers had been visited by beetles.

During the course of the study it was observed that the beetles (C. hardyi) copulated avidly when the males came in contact with the females outside the central flower cavity. Although this was observed in the laboratory in specimens brought in for study, in holding cages, and on the petals of the flowers in the field, no beetles were found copulating within the flowers when they were dissected. It is probable that limited space and the crowded conditions within the flower are the restricting factors.

No other frequent visitor was collected or observed at the flowers during our studies. We observed petal damage occasionally and this was attributed to Lepidopterous larvae of the family Tortricidae. We attempted to rear these larvae in the laboratory but without success, so we do not have an exact identification. The importance of these larvae to $V$. amazonica is minimal, and their presence is not frequent. The presence of Orthopterans, primarily crickets and grasshoppers, on the petals of first night flowers is also common and accounts for much of the petal damage. However, neither the Lepidopterous larvae nor the Orthopterans enter the flowers, and are at no time associated with the stamens or pollen of the flowers, which means that they are not pollinators of $V$. amazonica.

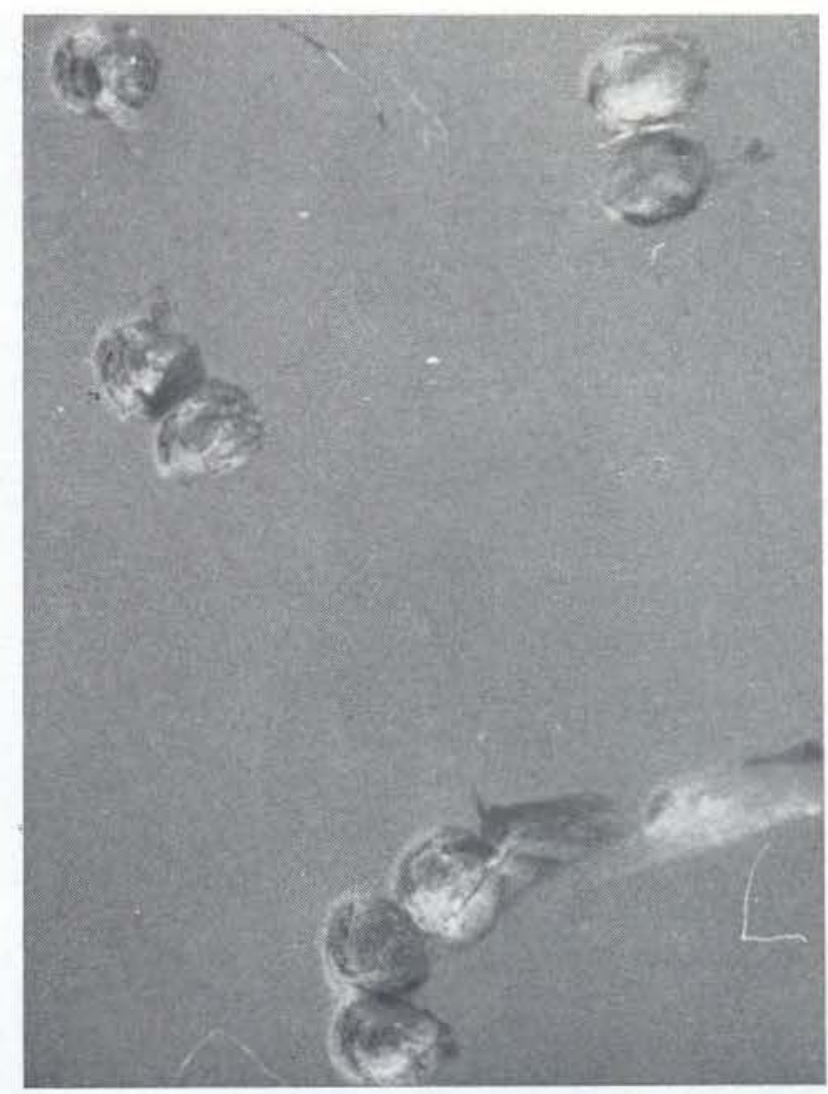

Fig. 17. Seeds of V. amazonica floating on the surface of the lake. 
An interesting additional snimal in the life cycle of $V$. amazonica is the Wattled Jaçana (Jacana jacana (Jacanidae)), locally called Piaçoca. This bird is common in all lakes with $V$. amazonica which we have visited, and it flies from leaf to leaf. Several times we found its nests containing 3-4 eggs built on the surfaces of leaves of $V$. amazonica. One evening when we were releasing a large number of beetles at dusk, we observed a Jacana catching and eating the beetles.

\section{SEED-SET}

A number of flower buds were placed in cages of fine mesh netting to investigate the effect of excluding beetles and any other possible vectors of pollen for cross-pollination. The flowers enclosed in cages produced seeds showing that self-fertilization is possible. Plants which were self-pollinated appeared to produce fewer seeds, though this is not absolutely certain because of the large variation in the seed-set of un-enclosed flowers. Table 5 gives details of thirteen capsules which were not in cages, and therefore had the possibility of cross-pollination. The large numerical variation demonstrates the difficulty of comparison of seed-set with the caged flowers, Table 6 . The relatively high seed-set in caged flowers shows that self-pollination is indeed possible, contrary to statements by several previous authors, for example Caspary (1855) and Decker (1936).

Table 5. Fruit set in normal flowers which were not caged.

\begin{tabular}{cl}
$\begin{array}{c}\text { Number of seeds } \\
\text { per capsuie } \\
88\end{array}$ & \multicolumn{1}{c}{ Observations } \\
334 & Heavy insect damage \\
135 & \\
233 & \\
256 & Light insect damage \\
383 & Light insect damage \\
176 & Heavy insect damage \\
525 & Light insect damage \\
584 & Light insect damage \\
275 & Heavy insect damage \\
146 & Heavy insect damage \\
711 & No insect damage \\
420 & Slight " damage
\end{tabular}

Table 6. Fruit set in caged flowers with pollinators excluded.

Number of
per caps
98
279
222
0
0

DISPERSAL OF SEEDS

After a flower has opened for the second night it slowly sinks to the bottom of the lake (Fig. 16), and gradually decomposes as the seeds mature. Each seed becomes surrounded by gelatinous tissue. When the pod is fully mature and the seeds are no longer secured by the decomposed pod, they break free and float up to the water surface, where they are dispersed by the water (Fig. 17). The possibility of dispersion over a considerable distance is increased by the annual flooding of most areas in which $V$. amazonica grows.

The seeds float for some time, so that the plant has a good capacity for dispersal when the rivers flood into the lakes. Floating seeds were also observed by Valla and Cirino. (1972).

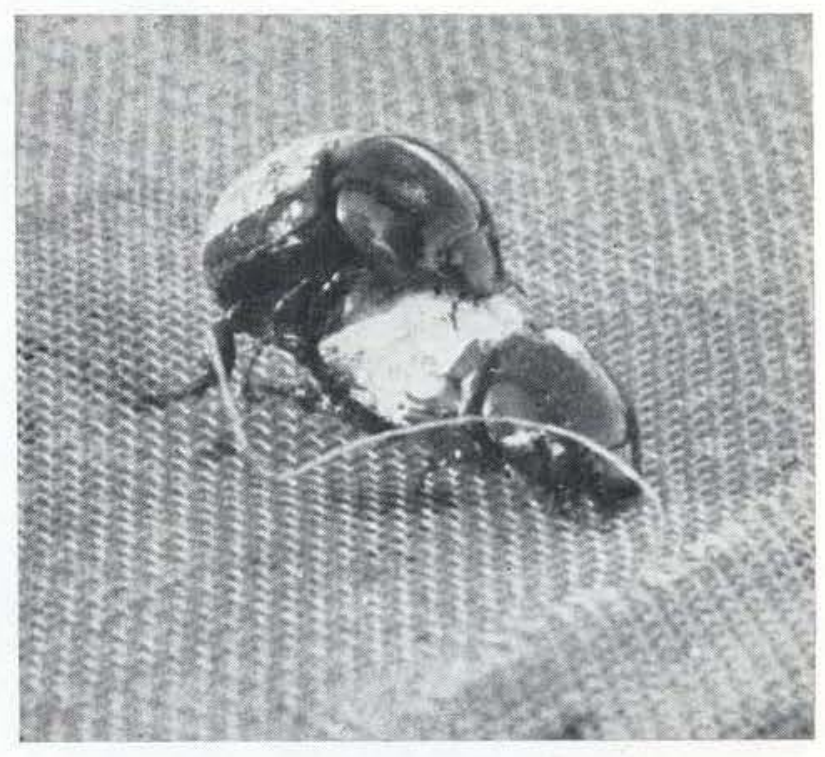

Fig. 18. A pair of Cyclocephala castanea copulating on holding cage. 


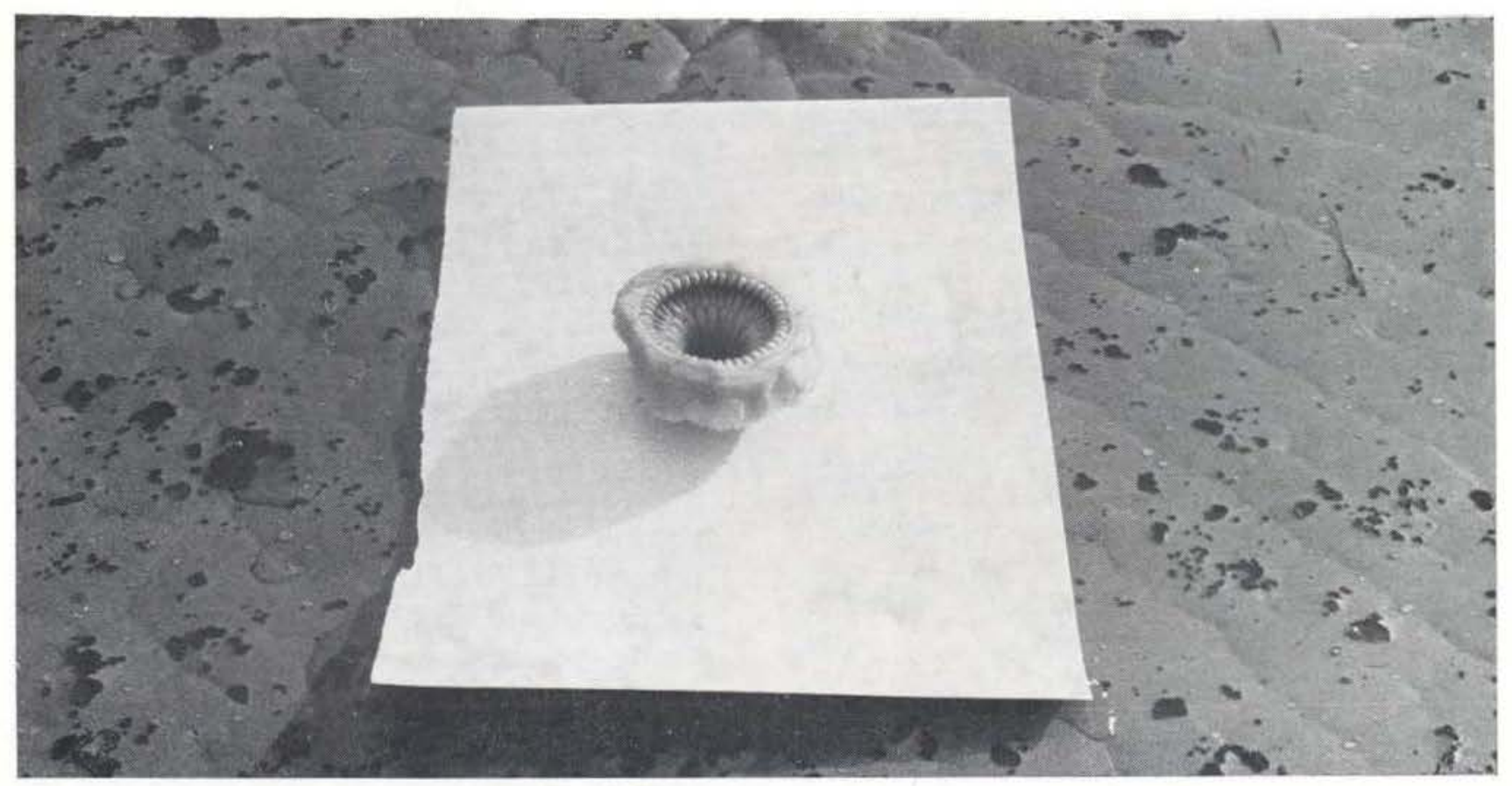

Fig. 19. Paracarpels and carpels on white card, as used in attraction experiments.

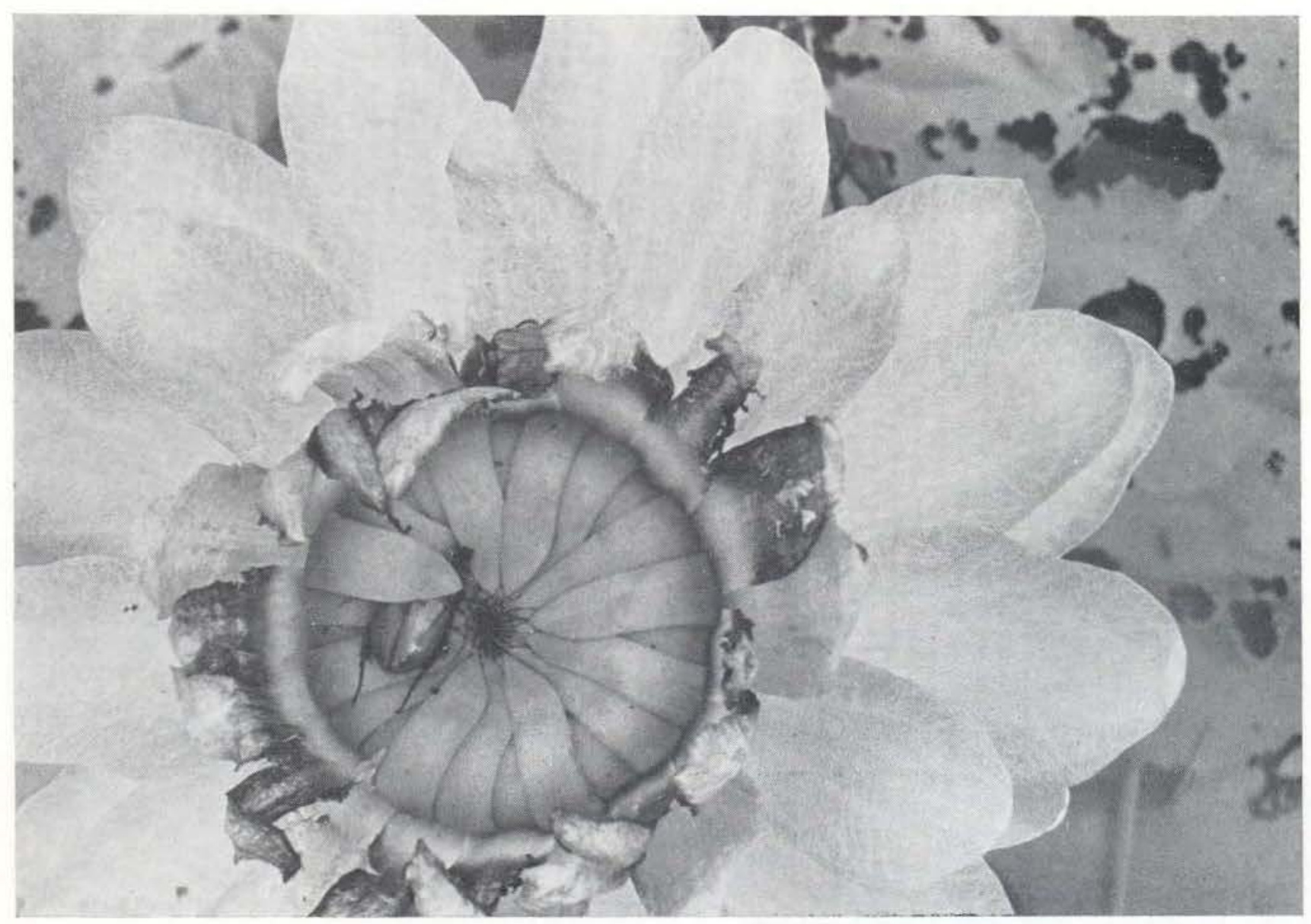

Fig. 20. Second day flower with two individuals of Cyclocephala hardyi which have just pushed their way out of the centre. One beetle is half under one of the staminodes. 
NUMBER OF FLORAL PARTS

As there is variation in the recorded number of floral parts of $V$. amazonica in the taxonomic literature, and as these have been used as taxonomic characters within the genus, we took the opportunity to count the numbers of the different floral parts. The result of this count is given for one hundred flowers in Table 7 . The results may be summed up as follows:

\begin{tabular}{|c|c|c|c|c|}
\hline & Minimum & Maximum & $\begin{array}{l}\text { Range of } \\
\text { Variation }\end{array}$ & $\overline{\mathbf{x}}$ \\
\hline Number of staminodes & i4 & 35 & 21 & 24.05 \\
\hline Fertile stamens & 104 & 327 & 223 & 204.34 \\
\hline Paracarpels & 27 & 63 & 36 & 44.57 \\
\hline Carpellary appendages & 24 & 46 & 22 & 37.20 \\
\hline
\end{tabular}

This demonstrates the variation in the numbers of the floral parts. There is also, however, considerable variation in flower size, and this can be correlated to some extent with the growing conditions. The flowers tend to be smaller in plants which are growing in less than $50 \mathrm{~cm}$. of water, or where the leaves are cramped for space. In ideal conditions with plenty of surface space, and with a water depth of between $50 \mathrm{~cm}$. and $150 \mathrm{~cm}$. the flowers are generally larger.
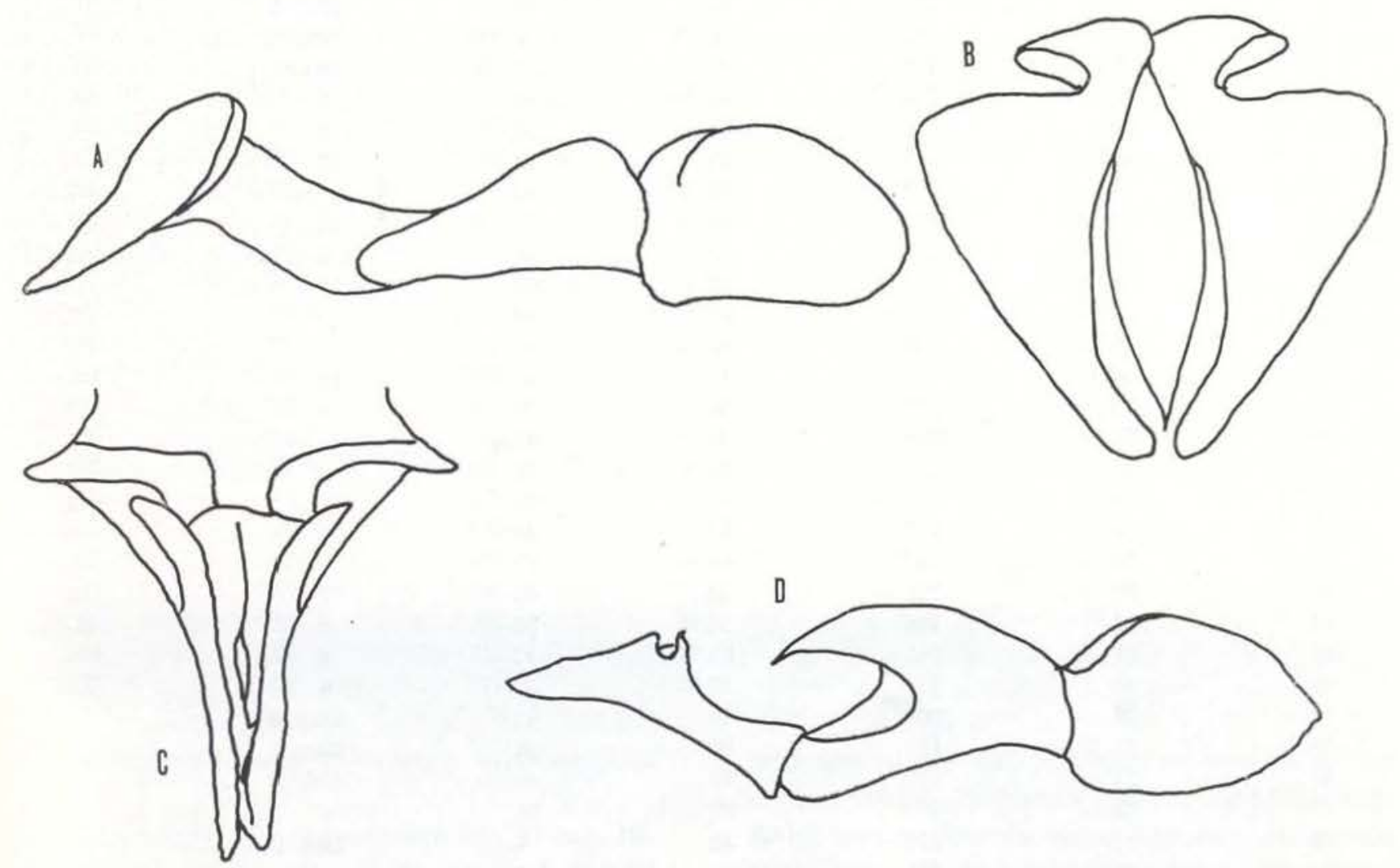

$5 \mathrm{~mm}$

Fig. 21. Male genitalia of Cyclocephala sp. A-B, C. castanea; A, lateral view of paramere; B, frontal view of paramere. C.D, C. hardyi; C, frontal view of paramere; D, lateral view of paramere. 
TABLE 7. Sample data on floral part number and beetle frequency for one hundred flowers of Victoria amazonica

\begin{tabular}{|c|c|c|c|c|c|c|c|}
\hline $\begin{array}{l}\text { Flower } \\
\text { number }\end{array}$ & Staminodes & $\begin{array}{c}\text { Fertile } \\
\text { stamens }\end{array}$ & $\begin{array}{l}\text { Para- } \\
\text { carpels }\end{array}$ & $\begin{array}{l}\text { Carpellary } \\
\text { appendages }\end{array}$ & C. hardyi & & $\begin{array}{l}\text { etles } \\
\text { C. verticalis }\end{array}$ \\
\hline 1 & 24 & 187 & 47 & - & 6 & & \\
\hline 2 & 19 & 178 & 40 & 34 & Bud & & \\
\hline 3 & 26 & 215 & 44 & 35 & Bud & & \\
\hline 4 & 20 & 253 & 46 & 46 & 5 & & \\
\hline 5 & 29 & 158 & 38 & 33 & - & & 1 \\
\hline 6 & 26 & 129 & 34 & 28 & - & & - \\
\hline 7 & 22 & 171 & 41 & 31 & Buẫ & & \\
\hline 8 & 23 & 176 & 43 & 33 & Bud & & \\
\hline 9 & 17 & 146 & 36 & 29 & Bud & & \\
\hline 10 & 18 & 174 & 36 & 29 & Day 2 & eaten & \\
\hline 11 & 22 & 202 & 40 & 37 & Day 2 & eaten & \\
\hline 12 & 15 & 199 & 46 & 39 & 4 & & \\
\hline 13 & 14 & 177 & 40 & - & 4 & & \\
\hline 14 & 18 & 153 & 38 & 26 & 2 & & \\
\hline 15 & 20 & 159 & 41 & - & Day 2 & eaten & \\
\hline 16 & 14 & 153 & 34 & - & 5 & & \\
\hline 17 & 19 & 210 & 47 & 37 & Bud & & \\
\hline 18 & 29 & 169 & 46 & 40 & Bud & & \\
\hline 19 & 31 & 186 & 45 & 33 & - & & 1 \\
\hline 20 & 24 & 199 & 46 & 41 & - & & \\
\hline 21 & 20 & 234 & 46 & 40 & Day 2 & & \\
\hline 22 & 16 & 202 & 51 & 39 & Day 2 & & \\
\hline 23 & 21 & 199 & 47 & 35 & Bud & & \\
\hline 24 & 25 & 185 & 34 & 40 & 5 & & \\
\hline 25 & 19 & 196 & 46 & 38 & 5 & & \\
\hline 26 & 26 & 238 & 54 & 41 & 12 & & \\
\hline 27 & 24 & 207 & 24 & 43 & 4 & & 2 \\
\hline 28 & 28 & 232 & 49 & 31 & 21 & & \\
\hline 29 & 24 & 222 & 49 & 40 & 5 & & 1 \\
\hline 30 & 31 & 228 & 46 & 39 & 5 & & \\
\hline 31 & 28 & 234 & 47 & 37 & - & & 1 \\
\hline 32 & 26 & 195 & 49 & 41 & - & & 2 \\
\hline 33 & 24 & 211 & 47 & 40 & 11 & & - \\
\hline 34 & 33 & 185 & 46 & 39 & 4 & & 2 \\
\hline 35 & 21 & 200 & 49 & 41 & - & & 1 \\
\hline 36 & 45 & 157 & 42 & 37 & 9 & & 1 \\
\hline 37 & 24 & 211 & 45 & 42 & 3 & & 2 \\
\hline 38 & 28 & 219 & 52 & 44 & 5 & & - \\
\hline 39 & 24 & 197 & 46 & 37 & 5 & & \\
\hline 40 & 30 & 218 & 39 & 40 & 7 & & 1 \\
\hline 41 & 24 & 206 & 50 & 39 & 9 & & - \\
\hline 42 & 31 & 241 & 63 & 37 & 6 & & - \\
\hline 43 & 16 & 173 & 39 & - & 8 & & - \\
\hline 44 & 28 & 209 & 46 & 41 & Day 2 & & i \\
\hline 45 & 22 & 194 & 52 & 38 & Day 2 & & \\
\hline 46 & 24 & 228 & 53 & 43 & Day 2 & & \\
\hline 47 & 33 & 192 & 27 & 24 & 4 & & \\
\hline 48 & 27 & 224 & 49 & - & Day 2 & & \\
\hline 49 & 23 & 269 & 49 & 42 & 1 & & \\
\hline 50 & 23 & 192 & 43 & 35 & - & & \\
\hline 51 & 18 & 219 & 47 & - & Day 2 & & \\
\hline 52 & 23 & 206 & 46 & 40 & Day 2 & & \\
\hline 53 & 21 & 210 & 43 & - & Day 2 & & \\
\hline 54 & 22 & 168 & 41 & - & Day 2 & & \\
\hline 55 & 31 & 223 & 52 & 40 & Day 2 & & \\
\hline
\end{tabular}


Table 7. Cont.d

\begin{tabular}{|c|c|c|c|c|c|c|}
\hline $\begin{array}{l}\text { Flower } \\
\text { number }\end{array}$ & Staminodes & $\begin{array}{c}\text { Fertile } \\
\text { stamens }\end{array}$ & $\begin{array}{c}\text { Para- } \\
\text { carpels }\end{array}$ & $\begin{array}{l}\text { Carpellary } \\
\text { appendages }\end{array}$ & C. hardyi & $\begin{array}{l}\text { Beetles } \\
\text { C. verticalis }\end{array}$ \\
\hline 56 & 28 & 217 & 45 & - & Day 2 & \\
\hline 57 & 24 & 226 & 46 & - & Day 2 & \\
\hline 58 & 23 & 234 & 47 & 41 & Day 2 & \\
\hline 59 & 28 & 119 & 40 & - & - & 1 \\
\hline 60 & 26 & 232 & 53 & 40 & Bud & \\
\hline 61 & 23 & 222 & 45 & 35 & Bud & \\
\hline 62 & 20 & 202 & 40 & 40 & Bud & \\
\hline 63 & 33 & 209 & 49 & 36 & Bud & \\
\hline 64 & 17 & 183 & 38 & 36 & Bud & \\
\hline 65 & 26 & 216 & 53 & 40 & Bud & \\
\hline 66 & 28 & 232 & 43 & - & 6 & 2 \\
\hline 67 & 22 & 184 & 40 & - & Day 2 & \\
\hline 68 & 24 & 193 & 39 & - & Day 2 & \\
\hline 69 & 26 & 203 & 41 & - & Day 2 & \\
\hline 70 & 27 & 180 & 38 & - & Day 2 & \\
\hline 71 & 29 & 174 & 42 & 45 & Bud & \\
\hline 72 & 26 & 250 & 39 & - & Day 2 & \\
\hline 73 & 27 & 216 & 46 & 40 & Bud & \\
\hline 74 & 25 & 203 & 46 & 36 & Bud & \\
\hline 75 & 27 & 189 & 36 & - & Day 2 & \\
\hline 76 & 35 & 153 & 46 & - & Day 2 & \\
\hline 77 & 18 & 224 & 54 & 41 & - & \\
\hline 78 & 18 & 201 & 36 & 33 & - & \\
\hline 79 & 20 & 249 & 48 & 41 & Bud & \\
\hline 80 & 24 & 222 & 49 & - & Day 2 & \\
\hline 81 & 18 & 226 & 48 & 37 & Day 2 & \\
\hline 82 & 21 & 237 & 44 & 35 & - & 2 \\
\hline 83 & 28 & 240 & 42 & 39 & Day 2 & \\
\hline 84 & 20 & 184 & 41 & - & 16 & \\
\hline 85 & 21 & 257 & 44 & - & 15 & 1 \\
\hline $8 \varepsilon$ & 23 & 216 & 41 & - & 10 & \\
\hline 87 & 20 & 203 & 42 & - & Day 2 & \\
\hline 88 & 21 & 225 & 41 & - & Day 2 & \\
\hline 89 & 31 & 215 & 46 & - & Day 2 & \\
\hline 90 & 25 & 212 & 50 & 39 & Day 2 & \\
\hline 91 & 24 & 207 & 44 & - & Day 2 & \\
\hline 92 & 26 & 209 & 52 & - & Day 2 & \\
\hline 93 & 29 & 327 & 55 & - & Day 2 & \\
\hline 94 & ? & 277 & 46 & - & Day 2 & \\
\hline 95 & 26 & 130 & 41 & - & 5 & \\
\hline 96 & 25 & 189 & 44 & - & 13 & \\
\hline 97 & 20 & 158 & 34 & - & 6 & \\
\hline 98 & 21 & 104 & 35 & - & 4 & \\
\hline 99 & 24 & 183 & 48 & - & 8 & \\
\hline 100 & 20 & 131 & 38 & - & 2 & \\
\hline
\end{tabular}

CANTHAROPHILY AND PRIMITIVE ANGIOSPERMS

This study of $V$. amazonica has shown the extremely complicated mechanism of beetle pollination. Until recently the tendency has been" to regard all forms of cantharophily as the primitive pollination type of the Angiosperms. However, it seems that the pollination of $V$. amazonica is a highly special- ized and hiyhly evolved mechanism. Primitive cantharophily occurred when unspecialized Angiosperm flowers were casually pollinated by beetles. Only later did more sophisticated types of cantharophily develop, accompanied by enlargement of the flower, reduction of the inflorescences, increase in the number of stamens and carpels, provision of separate feeding tissue for the beetles, mechanisms to 
trap the beetles inside the flowers, etc. We do not regard Victoria amazonica as an example of primitive cantharophily, but we agree with Gottsberger (1974), that the most primitive flowers are those of middle size and which are grouped in lateral flower clusters or inflorescences, and not those which are large and single, and placed terminally.

\section{ACKNOWLEDGEMENTS}

We are grateful to the Instituto Nacional de Pesquisas da Amazônia, Manaus, who made this study possible by the loan of equipment, and by providing the fuel for travelling. Part of the field work was carried out with the support of Grant GB - 32575 from the National Science Foundation, made to the senior author. We are particularly grateful to Sr. Francisco Jacob Nogueira caretaker of the property of Santa Terezinha where most of the observations were made. We are also grateful to our numerous friends and assistants who participated in the field trips, and who made observations during the day and the night: especially Mr. Malcolm Leppard, Mr. David Wendell, Sr. Rui Freitas, Sr. José Ramos, Sr. Francisco Mello, Dr. Walter Hödel, Mr. John Iles, Dr. Ivany Válio, and Mr. Robert McDougal. We would like to thank Dr. Sebo Endrödi of the Hungarian Museum in Budapest for identifications of the beetles, and Dr. Alan Hardy who gave us the preliminary identifications, and the name of Dr. Endrödi. We are especially grateful to Dr. Ivany Válio for working with us on the effect of light on the flower opening and the anthocyanin formation in the petals, and to Dr. Gerhard Gottsberger for a critical reading of our manuscript. We are also grateful to Eng. Florestal Pedro Nonato Conceição and Mrs. Anne Prance for the preparation of graphs and diagrams. The Indian legend was supplied by Professor Mário Ypiranga Monteiro, and the details of the cultivation of $V$. amazonica in Belém were given by Dr. P. B. Cavalcante. Dr. Hakumat Rai kindly loaned equipment and made some water analysis form us. Dr. Edward Schneider and Dr. W. H. Weidlich have offered helpful suggestions in correspondence. We would like to thank Mrs. Kathy Arias and Mr. Alex
Lasseigne for help in counting floral parts. Finally our special thanks are due to Sra. Osmarina Santos de Oliveira for her patience in typing the manuscript in several drafts.

Dr. B. J. D. Meeuse kindly informed us of his growing experiments of Victoria in Seattle.

\section{SUMÁrIo}

Foi feito um estudo da biologia floral de Victoria amazonica (Poepp.) Sowerby (Nymphaeaceae) da região de Manaus, para comparar com os estudos feitos em laboratório por outros pesquisadores. Na área estudada, Município do Careiro, foram encontradas quatro espécies de besouros do gênero Cyclocephala (Scarabaeidae: Dynastinae). A espécie de besouro mais comum na área é uma espécie nova, e foi descrita pelo Dr. Sebo Endrödi, de Budapest. Esta espécie nova, C. hardyi, foi encontrada em noventa por cento $(90 \%)$ das flores examinadas. As flores da Victoria atraem os besouros no primeiro dia em que elas se abrem, pelo aroma forte e pela cor branca das flores. Os besouros ficam presos dentro das flores por 24 horas, e alimentam-se dos apêndices dos carpelos, que possuem muito amido. Também foram feitas observações quanto a temperatura das flores. As flores quando abrem, podem apresentar uma temperatura de $9.5^{\circ} \mathrm{C}$ acima da temperatura do ar, devido às reações químicas proçuzindo o aroma. São apresentados ainda dados sobre a frequêencia dos besouros nas flores, o número de peças florais da V. amazonica, dispersão das sementes, e sobre a evolução de cantarofila.

\section{REFERENCES CITED}

Arber, A.

1920 - Water plants: a study of aquatic angiosperms. Cambridge.

ARCHANGeli, G,

1968 - Studi Sulla Victoria regia Lindl. Atti Soc. Tosc. Sci. Nat. Pisa Mem, 24: 59-78.

BAKER, H. G.

1955 - Self compatibility and establishment after "long-distance" dispersal. Evolution, 9: 347-348.

1961 - Pollination mechanisms and inbreeders. Rapid speciation in relation to changes in the breeding systems of plants. In: Recent Advances in Botany, : 881-885. Toronto.

CASPARY, R.

$1855 \mathrm{a}$ - Über die Wärmeentwicklung in der Blüte von Victoria regia, mitgeteilt von Professor Braun. Mber. Kgl. Preuss. Akad. Wiss. Berlin, : 711-756. 
$1855 \mathrm{~b}$ - Uber die Wärmeentwickelung in der Blüte von Vietoria regia Lindl. Bon. plandia, 3: 178 .

1878 - Nymphaeaceae: In, Mart. Fl. Bras. 4 (2): 143-154.

DECKER, J. S.

1936 - Aspectos biológicos da flora brasileira: 50-52. São Leopoldo, Rio Grande do Sul.

ENDRöDI, S.

1966 - Monografie der Dynastinae: Einleitung u. 1. Tribus: Cyclocephalini Entomol Abhandl., Dresden, 34: 1-460.

1968 - Neue Arten der Pentodontini (Col. Dy. sastinae). Folia Ent. Hungarica, 2 (12): $161-177$.

1969 - Monografie der Dynastinae: 4 Tribus: Pentodontini. Entomol, Abhandl., Dres. den, 37: 1-145.

1975 - Folia Ent. Hungarica. (In press).

FITCH W. H. \& W. J. HOOKER

1851 - Victoria regia, or Illustrations of the Royal Water-lily, in a series of figures chiefly made from specimens flowering at Syon and at Kew. London.

Fondeville, J. C., Borthwick, H. A. \& S. B. Hendricks

1966 - Leaf movement of Mimosa pudica L. Indicative of Phytochrome action. Planta, Berlin 69: 357-364.

GESSNER, F.

1950 - Die Stomatoden des Victoria-Blattes. Planta 58: 123-131.

1960 - Die Blütenöffnung der Victoria regia in ihrer Beziehung zum Licht. Planta, 54: 453-63.

1962 - A abertura das flores de Victoria regia em relação a luz. Bol. Mus. Goeldi, N. Ser.: Botânica, 17: 1-13.

GOTTSBERCER, G.

1974 - The structure and function of the primitive Angiosperm flower - a discussion. Acta. Bot. Neerl., 23 (4): 461-471.

Heinsbroek, P. G. \& Van Heel, W. A.

1969 - Note on the bearing of the pattern of vascular bundles on the morphology of the stamens of Victoria amazonica (Poepp.) Sowerby. Proc. Koninkl. Nederi. Akad, van Wetensch., 72 (4): 431-444.

HOOKER, W. J.

1847 - Victoria regia. Bot. Mag., III, tab. $4275-4278$.

KNÖCH, E.

1899 - Untersuchungen über die Morphologie, Biologie und Physiologie der Blüte von Victoria regia. Bibl. Bot., 47: 1-60.
KNOLL, F.

1956 - Die Biologie der Blüte. Berlin.

KUGLER, H.

1970 - Bï̈tenökologie. Stuttgart.

LANGlet, O. F. J. \& Söderberg, E.

1929 - Uber die Chromosomenzahlen einiger Nymphaeaceen. Acta Hort. Bergiani, 9 (4): 85-104.

LINDLEY, $\mathbf{J}$.

1838 - Victoria regia. Bot. Register (Misc. Not. 13): $9-14$

Malme, $x_{0}$ O. A: N.

1907 - Nagra Anteckningar om Victoria Lind1., Särskildt om Victoria cruziana D'Orb. Acta Hort. Bergiani, 4 (5): 3-16.

MEEUSE, B. J. D. 1951 - The story of pollination. New York. Orтo, E.

1852 - On the increase of temperature in the flowers of Victoria regia. Hook. J. Bot. Kew Gard. Misc. 4: 62-63. (Translated from Neue Allg. Deutsche Garten-Blumenzeitung, $7: 2$, 1851).

PERCIVAL, M. S.

1965 - Floral Biology. Pergamon Press.

Planchon, J. E.

1850 - La Victoria regia au point de vue horticole et botanique. Fl. Serres Jard. Eur., 6: 193-224, 249-254.

1851 - Idem, 7: 25-29, 49-53.

Prance, G. T.

1974 - Victoria regia ou Victoria amazonica? Acta Amazonica, Manaus, 4 (3): 5-8.

SCHOMBURGK, ROBERT H.

1837 - Dr. Robert H. Schomburgk's description of Victoria Regina Gray. Mag. Zool. Bot., 2: 440-442.

SCHUMANN, K.

1894 - Die untersuchungen des Herrn Raciborski uber die Nymphaceae. Ber, d Deutsch. Bot. Gesellsch., 12: 173-178.

SCULTHORPE, C. D.

1967 - The biology of Aquatic Vascular Plants. London.

THERESE, PRINZESSIN YON BAYERN

1897 - Meine Reise in den brasilianischen Tro. pen. Berlin. 544p

VALlA, J. J. \& CiRINo, D. R.

1972 - Biologia floral del Irupé, Victoria cru. ziana D.'Orb (Nymphaeaceae). Darwiniana, 17: 477-500.

VOGEL, S.

1962 - Deftdrüsen im Dienste der Bestäaubung. Akad. Wiss. Abh. Math. - Naturhwiss, K1. 10: 599-763. Mainz \& Wiesbaden.

WERTH, E.

1956 - Bau und Leben der Blumen. Stuttgart. 